\title{
Flow Cytometry Contributions for the Diagnosis and Immunopathological Characterization of Primary Immunodeficiency Diseases With Immune Dysregulation
}

OPEN ACCESS

Edited by:

Tomas Kalina,

Charles University, Czechia

Reviewed by:

Kimberly Gilmour,

Great Ormond Street Hospital for Children NHS Foundation Trust,

United Kingdom

Julian Joseph Bosco,

The Alfred Hospital, Australia

*Correspondence:

Otavio Cabral-Marques otavio.cmarques@gmail.com

Specialty section:

This article was submitted to Primary Immunodeficiencies,

a section of the journal

Frontiers in Immunology

Received: 02 September 2019 Accepted: 08 November 2019 Published: 26 November 2019

Citation:

Cabral-Marques O, Schimke LF, de Oliveira EB Jr, El Khawanky N, Ramos

RN, Al-Ramadi BK, Segundo GRS,

Ochs HD and Condino-Neto A (2019)

Flow Cytometry Contributions for the

Diagnosis and Immunopathological

Characterization of Primary

Immunodeficiency Diseases With

Immune Dysregulation.

Front. Immunol. 10:2742.

doi: 10.3389/fimmu.2019.02742

\begin{abstract}
Otavio Cabral-Marques ${ }^{1 *}$, Lena F. Schimke ${ }^{2}$, Edgar Borges de Oliveira Jr. ${ }^{3}$, Nadia El Khawanky ${ }^{4,5}$, Rodrigo Nalio Ramos ${ }^{6}$, Basel K. Al-Ramadi ${ }^{7}$, Gesmar Rodrigues Silva Segundo ${ }^{8}$, Hans D. Ochs ${ }^{9}$ and Antonio Condino-Neto ${ }^{1}$
\end{abstract}

${ }^{1}$ Department of Immunology, Institute of Biomedical Sciences, University of São Paulo, São Paulo, Brazil, ${ }^{2}$ Department of Rheumatology and Clinical Immunology, Faculty of Medicine, Center for Chronic Immunodeficiency (CCI), Medical Center-University of Freiburg, University of Freiburg, Freiburg im Breisgau, Germany, ${ }^{3}$ Immunogenic Inc., São Paulo, Brazil, ${ }^{4}$ Department of Hematology, Oncology and Stem Cell Transplantation, Freiburg University Medical Center, Freiburg im Breisgau, Germany, ${ }^{5}$ Precision Medicine Theme, The South Australian Health and Medical Research Institute (SAHMRI), Adelaide, SA, Australia, ${ }^{6}$ INSERM U932, SiRIC Translational Immunotherapy Team, Institut Curie, Paris Sciences et Lettres Research University, Paris, France, ${ }^{7}$ Department of Medical Microbiology and Immunology, College of Medicine and Health Sciences, UAE University, Al Ain, United Arab Emirates, ${ }^{8}$ Department of Pediatrics, Federal University of Uberlandia Medical School, Uberlândia, Brazil, ${ }^{9}$ Department of Pediatrics, University of Washington School of Medicine, and Seattle Children's Research Institute, Seattle, WA, United States

Almost 70 years after establishing the concept of primary immunodeficiency disorders (PIDs), more than 320 monogenic inborn errors of immunity have been identified thanks to the remarkable contribution of high-throughput genetic screening in the last decade. Approximately 40 of these PIDs present with autoimmune or auto-inflammatory symptoms as the primary clinical manifestation instead of infections. These PIDs are now recognized as diseases of immune dysregulation. Loss-of function mutations in genes such as FOXP3, CD25, LRBA, IL-10, IL10RA, and IL10RB, as well as heterozygous gain-of-function mutations in JAK1 and STAT3 have been reported as causative of these disorders. Identifying these syndromes has considerably contributed to expanding our knowledge on the mechanisms of immune regulation and tolerance. Although whole exome and whole genome sequencing have been extremely useful in identifying novel causative genes underlying new phenotypes, these approaches are time-consuming and expensive. Patients with monogenic syndromes associated with autoimmunity require faster diagnostic tools to delineate therapeutic strategies and avoid organ damage. Since these PIDs present with severe life-threatening phenotypes, the need for a precise diagnosis in order to initiate appropriate patient management is necessary. More traditional approaches such as flow cytometry are therefore a valid option. Here, we review the application of flow cytometry and discuss the relevance of this powerful technique in diagnosing patients with PIDs presenting with immune dysregulation. In addition, flow cytometry represents a fast, robust, and sensitive approach that efficiently uncovers new immunopathological mechanisms underlying monogenic PIDs.

Keywords: flow cytometry, diagnosis, primary immunodeficiency diseases, immune dysregulation, mutation 


\section{INTRODUCTION}

An effective immune response is required for defending the host from infections as well as playing a fundamental role in physiological homeostasis (1-9). In this context, the investigation of inborn errors of immunity leading to primary immunodeficiency diseases (PIDs) has considerably expanded our understanding of how the immune system works to eliminate infections while avoiding autoimmune diseases (10-17). The first PID was identified in 1952 by Ogden Bruton who reported a male patient with agammaglobulinemia who suffered from recurrent bacterial infections (18). By 2003, mutations in approximately 100 genes were found to cause molecularly defined PIDs (19). The introduction of next-generation sequencing (NGS) (e.g., whole exome sequencing or WES; whole genome sequencing or WGS) led to the discovery of $\sim 120$ new genes by 2015 (20-23). The most recent International Union of Immunological Societies (IUIS) report lists more than 320 monogenic causes of PID (24).

The longitudinal observation and molecular evaluation of PID patients revealed that the phenotype of PID patients comprises not only the susceptibility to bacterial, fungal, and viral infections diseases, but also autoinflammatory and autoimmune disorders as well as an increased incidence of malignancies $(15,16,25-$ 28). The group of PIDs associated with inflammation and autoimmunity has been recognized by the IUIS Phenotypic Classification Committee for PIDs as "diseases of immune dysregulation" (24). The prototype for this group is the syndrome of Immune Dysregulation, Polyendocrinopathy, Enteropathy, Xlinked (IPEX) (29) caused by mutations in the Forkhead Box P3 (FOXP3) gene that results in the defective development of $\mathrm{CD} 4{ }^{+} \mathrm{CD} 25^{+}$regulatory $\mathrm{T}$ cells (Tregs). To date, mutations in some 40 genes have been identified that can present with symptoms of immune dysregulation [Figure 1; (24)]. Patients suspected to have one of these disorders require a rapid and precise diagnosis for prognostic and therapeutic considerations.

Although WES and WGS are powerful tools that have improved the genetic characterization of patients with undefined PIDs, these are laborious, time-consuming, and expensive tests. Flow cytometry, which is readily available in most laboratories, represents a useful low cost and rapid technology for the

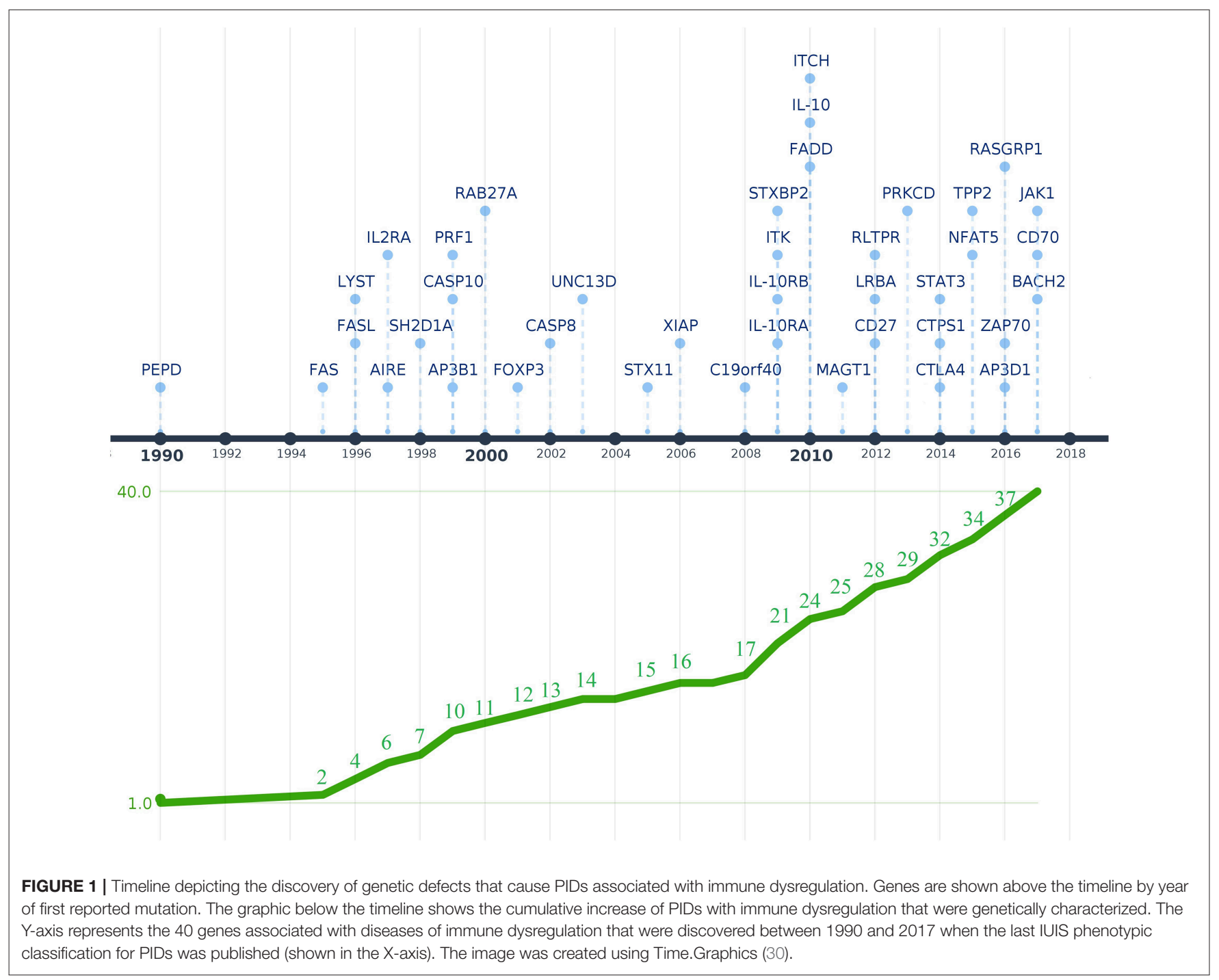


investigation of PIDs, including patients with symptoms of immune dysregulation. This tool can identify not only the abnormal expression of extra- and intracellular molecules but can also be used to assess functional responses of specific subpopulations of lymphocytes. Flow cytometry-based assays have the advantage of being more quantitative, widely available and relatively easier to perform in a diagnostic laboratory setting compared with other techniques such as western blot analysis, fluorescent and confocal microscopy.

The advantage of using flow cytometry for the diagnosis of PIDs, in general, has been extensively discussed (31-36). Here, we review the progress made in using flow cytometry for the diagnosis of PIDs associated with immune dysregulation and its contributions for a better understanding of disease immunopathology. Although the genetic dissection of several PIDs have provided relevant insights into molecular pathways associated with host defense and immune tolerance (24, 37-43), we discuss here only the inborn errors of immunity presented by the last IUIS phenotypic classification for PIDs in 2017 (44).

\section{Flow Cytometry for Diseases of Immune Dysregulation}

Since the first attempt by Cooper et al. to provide a classification for PIDs in 1973 (45), the number of PIDs have exponentially increased as most recently summarized by the IUIS Inborn Errors of Immunity Committee classification [Figure 1 (24)]. The first PIDs with features of immune dysregulation appeared in the IUIS Phenotypic Classification for Primary Immunodeficiencies in 1999 (Wiskott-Aldrich syndrome, PNP deficiency, selective IgA deficiency, early complement component deficiencies, and ALPS) (46). In subsequent reports, increased numbers of PIDs with features of immune dysregulation were reported, currently comprising a total of 40 monogenic diseases of immune dysregulation (Figure 2), divided into two main groups labeled "Hemophagocytic Lymphohistiocytosis (HLH) \& Epstein-Barr virus (EBV) susceptibility" and "Syndromes with Autoimmunity and Others" (Figure 3). We use this classification throughout this article. The genes causing these disorders are listed in Figure 4 (HLH and EBV susceptibility) and Figure 7 (syndromes with autoimmunity).

With a few exceptions, the flow cytometry contributions for the characterization of diseases of immune dysregulation are discussed below and summarized in Tables 1, 2. We have not included the Fanconi anemia-associated protein 24 (FAAP24) (91) and Itch E3 ubiquitin ligase (ITCH) (92) deficiencies, which are molecules that play a critical role in DNA repair $(91,93)$ and the negative regulation of $\mathrm{T}$ cell activation $(92,94)$. There are only single reports $(91,92)$ of these deficiencies and flow cytometry methods for the characterization of their immunopathological mechanisms are not available. This is also the case for prolidase $\mathrm{D}(P E P D)$ deficiency (95), which has been associated with the development of systemic lupus erythematosus (SLE) (96), and zeta chain of T cell receptor-associated protein kinase 70 (ZAP70) (97) and nuclear factor of activated T cells 5 (NFAT5) deficiencies (98). Only two ZAP-70-deficient siblings have been reported with combined hypomorphic and activation mutations,

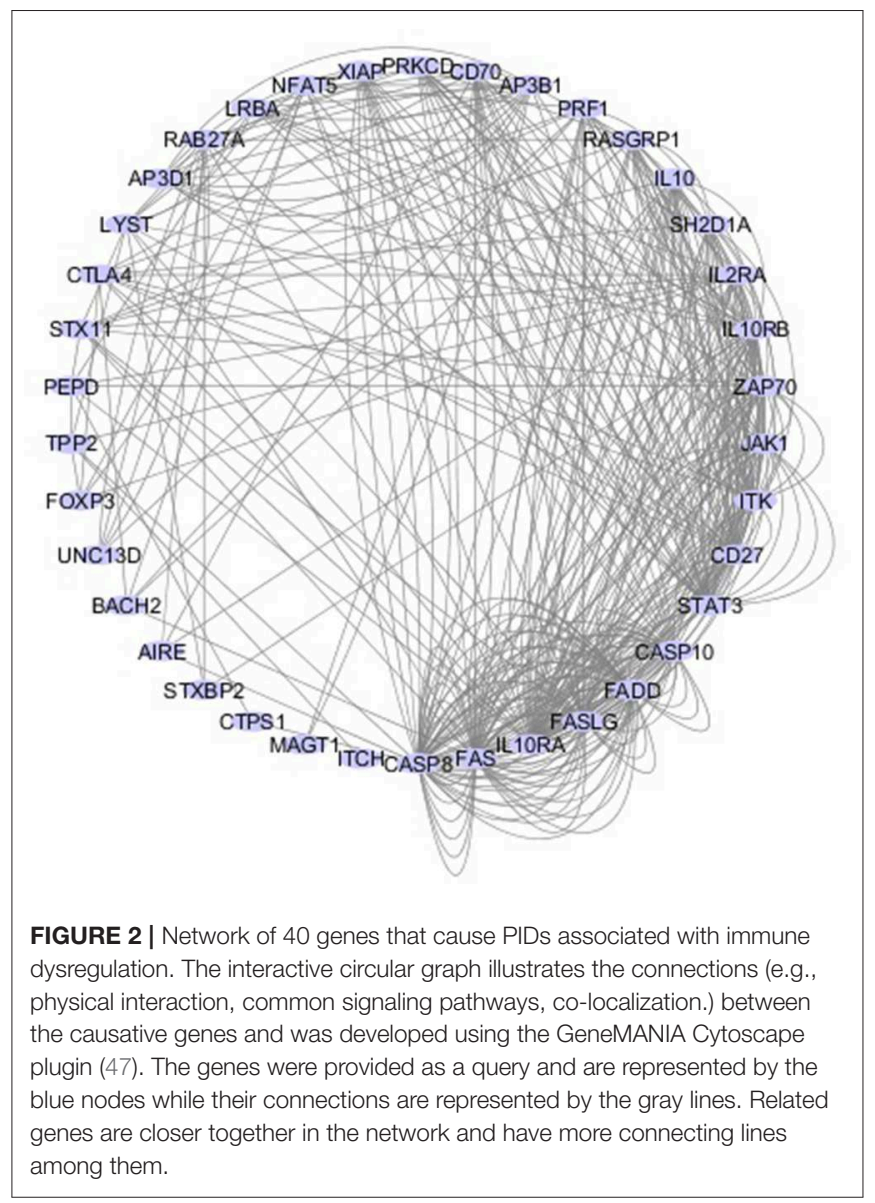

and flow cytometry was only used to analyze $\mathrm{T}$ cell activation by measuring CD69 expression on activated T cells. Only a single patient with NFAT5 deficiency was reported, for whom flow cytometry was used mainly for immunophenotyping and cell death analysis (98).

\section{Flow Cytometry Guidelines}

Before reviewing the contribution of flow cytometry to the characterization of PIDs with immune dysregulation, we emphasize that in order to perform molecular characterization of inborn errors of immunity in diagnostic laboratories, one needs to become familiar with the flow cytometry guidelines and parameters, which have been previously reported $(31,99-$ 104) They were discussed in detail with focus on technical flow cytometry aspects. For example, flow cytometry parameters of general importance are the determination and validation of flow cytometry positive controls (e.g., fluorescence compensation controls as well as resting and activation controls in the case of inducible molecules), the establishment of appropriate cutoffs (e.g., by defining the 10th percentile of normal controls as a center-specific lower limit of normal), and avoiding misinterpretation of results due to inter-laboratory variability, specificity, and sensitivity, particularly in patients with low peripheral blood lymphocyte counts. Another important issue is 


\begin{tabular}{|c|c|c|c|c|c|c|}
\hline \multicolumn{3}{|c|}{$\begin{array}{c}\text { Hemophagocytic lymphohistiocytosis } \\
\text { \& EBV susceptibility }\end{array}$} & \multicolumn{4}{|c|}{ Syndromes with Autoimmunity } \\
\hline$\downarrow$ & $\downarrow$ & $\downarrow$ & $\downarrow$ & & & $\downarrow$ \\
\hline $\begin{array}{l}\text { Hypopigmentation } \\
\text { syndromes }\end{array}$ & $\begin{array}{l}\text { Familial FHL } \\
\text { syndromes }\end{array}$ & $\begin{array}{l}\text { Susceptibility to EBV } \\
\text { infections }\end{array}$ & $\begin{array}{c}\text { Syndromes associated } \\
\text { with increased TCR } \alpha / \beta\end{array}$ & & & $\begin{array}{c}\text { Immune } \\
\text { dysregulation with }\end{array}$ \\
\hline LYST & PRF1 & RASGRP1 & FAS & FOXP3 & AIRE & IL-10 \\
\hline RAB27A & UNC13D & $\mathrm{CD} 70$ & FASL & $\mathrm{CD} 25$ & ITCH & IL-10Ra \\
\hline AP3B1 & STX11 & CTPS1 & CASP8 & CTLA4 & ZAP70 & IL-10Rb \\
\hline \multirow[t]{8}{*}{ AP3D1 } & STXBP2 & RLTPR & CASP10 & $\mathrm{BACH} 2$ & TPP2 & NFAT5 \\
\hline & & ITK & FADD & & JAK1 GOF & \\
\hline & & MAGT1 & LRBA & & PEPD & \\
\hline & & PRKCD & STAT3 GOF & & & \\
\hline & & SH2D1A & & & & \\
\hline & & XIAP & & & & \\
\hline & & $\mathrm{CD} 27$ & & & & \\
\hline & & FAAP24 & & & & \\
\hline
\end{tabular}

that some functional assays have a time frame (normally within $24 \mathrm{~h}$ after venous puncture) within the test must be performed, due to changes in cell viability or the activation of affected cell pathways during blood shipment. Thus, it is important to obtain blood from healthy controls at the same time of patient sampling and ship them together for flow cytometry screening tests $(49,105)$. In cases that the cells obtained from the same-day healthy control show results outside the normal range, i.e., not expressing or overexpressing a specific molecule, which is used as experimental readout such as in degranulation assays (49), the shipment and test have to be repeated. Altogether, the above mentioned factors as well as other experimental procedures such as correct definition of instrument setup and evaluation of cell viability prior to the experiment are of major importance for the proper execution of diagnostic flow cytometry. Importantly, following the initial flow cytometry screening tests, there is a significant amount of work to be performed by functional validation studies (e.g., by combining site-directed mutagenesis combined with flow cytometric assays) when identifying new molecular defects.

\section{HEMOPHAGOCYTIC LYMPHOHISTIOCYTOSIS AND EBV SUSCEPTIBILITY}

HLH is a hyper-inflammatory syndrome directly linked to abnormalities in cytotoxicity as a result of defective degranulation. This syndrome is characterized by prolonged fever and massive hepatosplenomegaly associated with laboratory findings such as cytopenia, hypertriglyceridemia, hypofibrinogenemia, and NK cells and cytotoxic $\left(\mathrm{CD}^{+}\right) \mathrm{T}$ lymphocytes (CTLs) exhibiting reduced cytotoxicity $(24,106)$. Clinical and immunological features of FHL syndromes have previously been reviewed in detail $(107,108)$. Natural killer (NK) and cytotoxic $\mathrm{T}$ cells from these patients show an impaired capacity to control viral infections. The unique curative therapy for HLH is hematopoietic stem cell transplantation (HSCT) (109-111).

Several different genetic disorders are associated with an HLH phenotype and are classified as HLH with hypopigmentation or without hypopigmentation (familial hemophagocytic lymphohistiocytosis syndromes or FHL). Secondary HLH, generally seen in older children and adults without a known genetic defect, are triggered by viral infections such as EBV (most commonly), cytomegalovirus, and herpes simplex virus, or by hematologic malignancies, rheumatologic conditions, or tuberculosis (112). The 19 causative genes associated with the HLH and EBV susceptibility group are summarized in Figure 4 as well as a summarized guideline is shown in Figure 5, which describes the flow cytometric assays required to diagnose patients with syndromes that present with autoimmunity.

\section{Hypopigmentation Syndromes}

Four different inborn errors of immunity causing HLH with hypopigmentation/albinism have been described: ChediakHigashi syndrome, genetically characterized by mutations in the lysosomal trafficking regulator (LYST) gene (50, 51); Griscelli syndrome type 2 due to mutations in Ras-Related Protein Rab27A (RAB27A) (52); and Hermansky-Pudlak syndrome type 2 


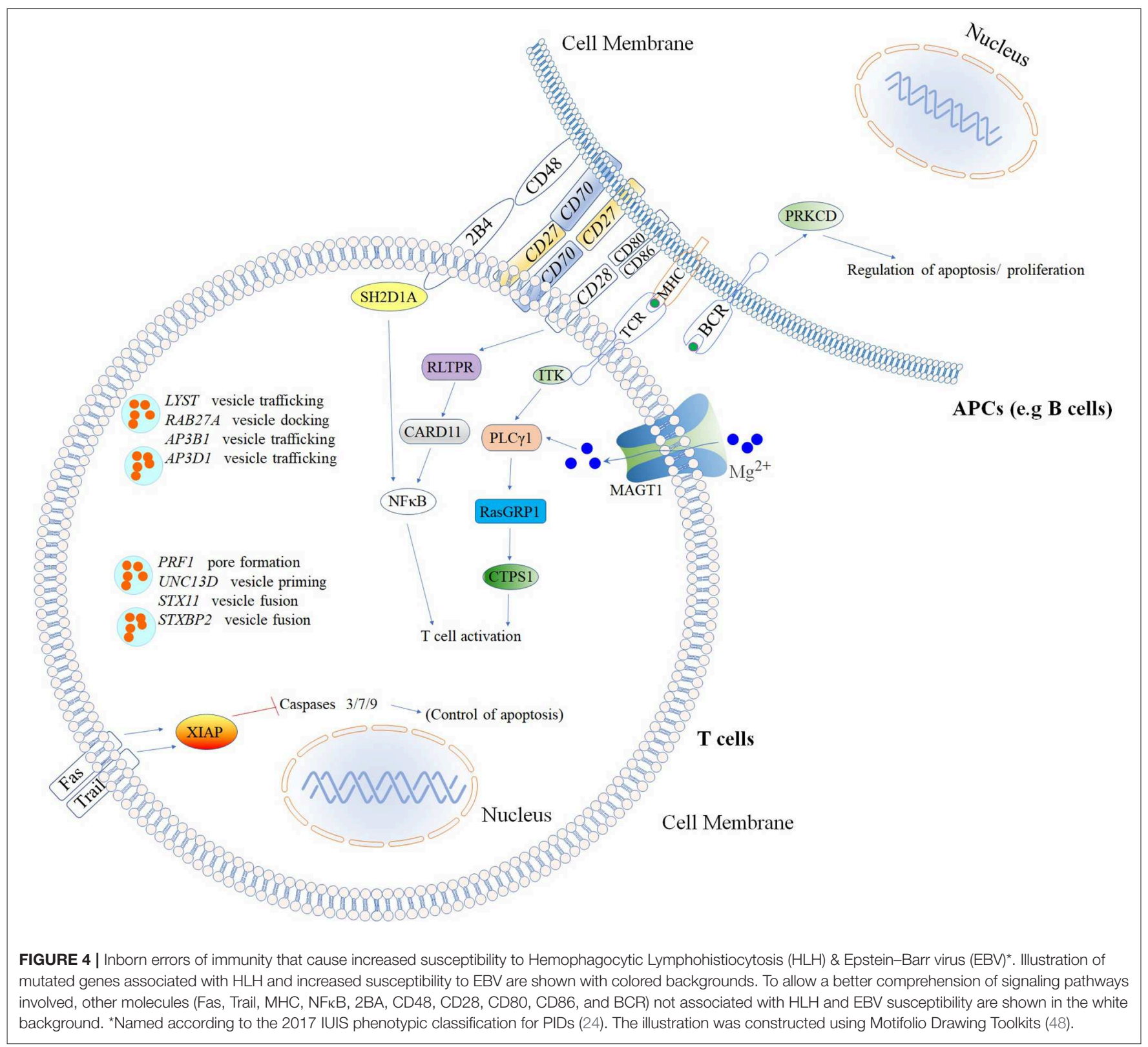

and type 10 caused by mutations in the adaptor related protein complex 3 beta 1 (AP3B1) (53) and adaptor related protein complex 3 delta 1 (AP3D1) (54), respectively. These diseases generally manifest as hypopigmentation, immunodeficiency, neutropenia, or decreased NK and cytotoxic T cell activity, and bleeding tendency. However, a few cases of patients with Griscelli syndrome type 2 with biallelic mutations in $R A B 27 A$ have been reported with normal pigmentation (113).

Interestingly, the overlapping clinical features shown by inborn errors of immunity causing HLH with hypopigmentation/albinism might be explained by defects in the molecular machinery responsible for the biogenesis and transport of secretory lysosome-related organelles in different cell types (54). These physiologic processes are essential for production and secretion of perforin and granzyme by $\mathrm{NK}$ cells and cytotoxic $\mathrm{CD}^{+} \mathrm{T}$ lymphocytes $(54,55)$, as well as secretion of melanin by melanosomes $(114,115)$ and release of small molecules by $\delta$ granules from platelets during blood vessel damage, which facilitates platelet adhesion and activation during coagulation (114).

Since there is no specific flow cytometry approach established to detect the expression of LYST, RAB27A, AP3B1, or AP3D1, the differential diagnosis of these syndromes, based on flow cytometry, is not possible and thus the diagnosis relies on biochemical and molecular criteria $(50,109,116)$. A few specific features differentiate these disorders, such as the presence of large inclusions (lysosome) in white blood cells from patients with Chediak Higashi syndrome $(49,50,116)$, specific hair shaft 
TABLE 1 | Summary of flow cytometry contributions for the immunopathological characterization of Hemophagocytic Lymphohistiocytosis (HLH) and Epstein-Barr virus (EBV) susceptibility.

\begin{tabular}{|c|c|c|c|}
\hline HLH and EBV susceptibility & Flow cytometric (FC) application and immunopathological mechanisms identified & $\begin{array}{l}\text { Genetic defect } \\
\text { (References) }\end{array}$ & Inheritance \\
\hline
\end{tabular}

Hypopigmentation Syndromes

Chediak Higashi sd

Griscelli sd type 2

Hermansky-Pudlak sd type 2

Hermansky-Pudlak sd, type 10

Familial HLH

Perforin deficiency (FHL2)

UNC13D or Munc13-4

deficiency (FHL3)

Syntaxin 11 deficiency (FHL4)

STXBP2 or Munc18-2 deficiency (FHL5)

Susceptibility to EBV infections RASGRP1 deficiency

\begin{abstract}
Reduced degranulation based on the surface up-regulation of CD107a (49) in Natural killer (NK) cells and cytotoxic T lymphocytes (CTLs)

Reduced degranulation based on the surface up-regulation of CD107a (49) in NK and CTLs

Reduced degranulation based on the surface up-regulation of CD107a (49) in NK and CTLs

Reduced degranulation based on the surface up-regulation of CD107a (49) in NK and CTLs
\end{abstract}

Perforin expression in NK cells and CTLs

Normal CD107a expression in NK and CTLs

Munc13-4 expression in NK cells, CTLs, and platelets.

STX11 expression not available by FC (no antibody validated).

Reduced CD107a expression in NK and CTLs

STXBP2 expression by FC not available (no antibody validated).

Reduced CD107a expression in NK and CTLs

Reduced cell proliferation using fluorescent cell staining dye; impaired T cell activation by measuring CD69 expression; defective CTPS1 expression; reduced intracellular expression of active caspase 3; reduced T cell apoptosis using annexin V/propidium iodide staining, all in response to $\mathrm{CD} 3 / \mathrm{TCR}$ activation

CD70 deficiency

CD70 expression on phytohaemagglutinin (PHA)-stimulated T cells; binding of a CD27-FC fusion protein on T cells

CTPS1 deficiency

RLTPR deficiency

Defective cell proliferation using fluorescent cell staining dye

RLTPR expression in adaptive (B and T lymphocytes) and innate (monocytes and dendritic

cells) immune cells. Reduced phospho-nuclear factor (NF)-кB P65-(pS259) expression and inhibitor $(\mathrm{I}) \mathrm{k} \mathrm{B} \alpha$ degradation in $\mathrm{CD} 4^{+}$and $\mathrm{CD}^{+}$, specifically after CD28 co-stimulation; CD107a expression after K562 stimulation

ITK deficiency

ITK expression by FC not available (no antibody validated). Reduced T cell receptor

(TCR)-mediated calcium flux; absence of Natural Killer T (NKT) cells determined as TCR V $\beta 11$ and TCR $V \alpha 24$ double-positive cells

MAGT1 deficiency

MAGT1 expression by FC not available (no antibody validated). Reduced CD69 expression in $\mathrm{CD}^{+}{ }^{+} \mathrm{T}$ cells after anti-CD3 stimulation. Low CD31+ cells in the naïve $\left(\mathrm{CD} 27^{+}, \mathrm{CD} 45 \mathrm{RO}^{-}\right)$ $\mathrm{CD}^{+}{ }^{+} \mathrm{T}$ cell population. Impaired Mg influx using $\mathrm{Mg}^{+}{ }^{-}$-specific fluorescent probe MagFluo4. Reduced NKG2D expression in NK cells and CTLs

PRKCD deficiency Increased B cell proliferation after anti-IgM stimulation; resistance to PMA-induced cell death; low CD27 expression on B cells

XLP1

XLP2

CD27 deficiency
SH2D1A expression, low numbers of circulating NKT cells ( $\alpha 24 T C R+N \beta 11 T C R+)$. Impaired apoptosis.

XIAP expression, low numbers of circulating NKT cells (V $\alpha 24 T C R+N \beta 11 T C R+)$. Enhanced apoptosis

CD27 expression on B cells
$\operatorname{LYST}(50,51) \quad$ AR

RAB27A (52) AR

AP3B1 (53) AR

$A P 3 D 1(54) \quad$ AR

PRF1 (55) AR

UNC13D (56) AR

STX11 (57) AR

STXBP2 (58) AR

RASGRP1 AR

(59-63)

CD70 (64) AR

CTPS1 (65) AR

RLTPR or

CARMIL2 (66)

ITK (67)

AR

MAGT1 (68) XL

PRKCD (69-71) AR

SH2D1A (72) XL

XIAP (73) XL

CD27 (74) AR

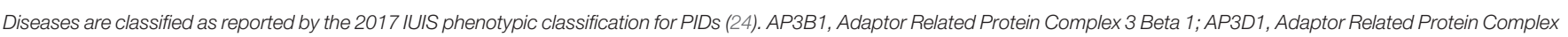

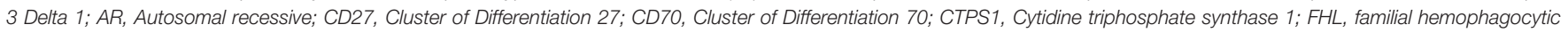

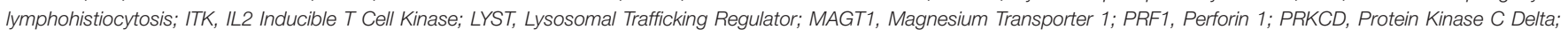

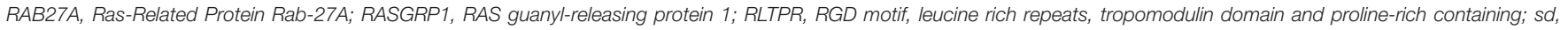

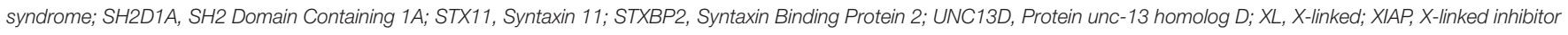
of apoptosis protein.

anomalies, and the detection of a platelet storage pool deficiency characteristic of Hermansky-Pudlak syndrome (54). However, flow cytometry has been used successfully as a screening tool for primary (i.e., genetic) degranulation defects. The approach relies on measuring the up-regulation of CD107a on NK cells (with/without K562 stimulation) (49) and cytotoxic T lymphocytes (with/without anti-CD3 stimulation) (54). CD107a is a lysosomal protein that co-localizes with perforin and granzyme in cytolytic granules $(117,118)$ and is expressed on the cell surface upon activation-induced degranulation following the engagement of T cell receptor (TCR) and NK cell activating receptors $(119,120)$. This assay has been performed in parallel with a cytotoxicity assay using K562 or P815 target cells to functionally confirm the degranulation defect suggested by a reduced CD107a expression following $48 \mathrm{~h}$ with phytohemagglutinin (PHA)/IL-2 or anti-CD3/anti-CD28 
TABLE 2 | Summary of flow cytometry contributions for the immunopathological characterization of Syndromes with autoimmunity.

\begin{tabular}{lll}
\hline Syndromes with autoimmunity $\quad$ Flow cytometric (FC) application and immunopathological mechanisms identified & $\begin{array}{l}\text { Genetic defect } \\
\text { (References) }\end{array}$ & $\begin{array}{l}\text { Inheritance } \\
\text { (R) }\end{array}$
\end{tabular}

Syndromes associated with increased TCR $\alpha / \beta$ DN T cells

\begin{tabular}{|c|c|c|c|}
\hline ALPS-FAS & FAS expression, reduced T cell apoptosis & TNFRSF6 (75) & $\mathrm{AD} / \mathrm{AR}$ \\
\hline ALPS-FASLG & FASL expression, reduced T cell apoptosis & TNFSF6 (76) & $\mathrm{AD} / \mathrm{AR}$ \\
\hline ALPS-Caspase8 & Reduced T cell apoptosis & CASP8 (77) & $A R$ \\
\hline ALPS-Caspase 10 & Reduced T cell apoptosis & CASP10 (78) & $A D$ \\
\hline FADD deficiency & Reduced T cell apoptosis & FADD (79) & $\mathrm{AR}$ \\
\hline LRBA deficiency & $\begin{array}{l}\text { Reduced T regulatory (T reg) cells, low CTLA4 and Helios; Increased B cell apoptosis and low } \\
\text { levels of IgG }{ }^{+} / \mathrm{IgA}^{+} \mathrm{CD} 27^{+} \text {switched-memory B cells; reduced B proliferative capacity, and } \\
\text { impaired activation (using CD138 staining) }\end{array}$ & LRBA (80) & $A R$ \\
\hline $\begin{array}{l}\text { STAT3 gain-of-function (GOF) } \\
\text { mutation }\end{array}$ & $\begin{array}{l}\text { Delayed de-phosphorylation of STAT3; diminished STAT5 and STAT1 phosphorylation; which is } \\
\text { in line with the role in the negative regulation of several STATs162. High levels of Th17 cells; } \\
\text { reduced FOXP3 }{ }^{+} \text {CD25+ Treg population; decreased FASL-induced apoptosis }\end{array}$ & STAT3 (81) & $A D$ \\
\hline \multicolumn{4}{|l|}{ Defective regulatory $T$ cells } \\
\hline IPEX & Decreased or absent FOXP3 expression by $\mathrm{CD}^{+}{ }^{+} \mathrm{CD} 25^{+}$regulatory $\mathrm{T}$ cells & FOXP3 (82) & $X L$ \\
\hline CD25 deficiency & $\begin{array}{l}\text { Impaired CD25 expression; defective proliferative responses following anti-CD3 or PH; } \\
\text { defective NK cell maturation increased (CD56brightCD16hi and reduced CD56dimCD16hi NK } \\
\text { cells in peripheral blood); increased degranulation by elevated CD107a expression and higher } \\
\text { perforin and granzyme B expression in NK cells; }\end{array}$ & $\begin{array}{l}\text { CD25 or IL2RA } \\
\text { (83) }\end{array}$ & $A R$ \\
\hline CTLA4 haploinsufficiency & CTLA4 expression, trafficking, binding to its ligand, and CTLA4-mediated trans-endocytosis & CTLA4 (84) & $A D$ \\
\hline BACH2 deficiency & $\begin{array}{l}\text { Reduced BACH2 expression in T and B lymphocytes, decreased FOXP3 expression by } \\
\mathrm{CD} 4^{+} \mathrm{CD} 25^{+} \text {regulatory T cells, reduced total and class-switched memory B cells, increased } \\
\text { T-bet expression }\end{array}$ & $\mathrm{BACH} 2(85)$ & $A D$ \\
\hline \multicolumn{4}{|l|}{ Normal regulatory $T$ cell function } \\
\hline APECED & $\begin{array}{l}\text { Expression of IL-17A, IL-17F, and IL-22 by PBMCs. AIRE expression by FC is not available (no } \\
\text { antibody validated) }\end{array}$ & AIRE (86) & $\mathrm{AR}$ \\
\hline Tripeptidyl-Peptidase II deficiency & $\begin{array}{l}\text { Lymphocytes expressing high levels of major histocompatibility complex (MHC) class I } \\
\text { molecules, a predominant T CD } 8^{+} \mathrm{CD} 27^{-} \mathrm{CD} 28^{-} \mathrm{CD} 127^{-} \text {phenotype; increased percentage of } \\
\text { IFN- } \gamma \text { and IL-17 positive T cells; high expression of T-bet and perforin. Defective proliferation } \\
\text { lymphoproliferation and increased susceptibility to apoptosis; increased levels of CD21low B } \\
\text { cells }\end{array}$ & TPP2 (87) & $\mathrm{AR}$ \\
\hline JAK1 GOF & Increased JAK1, STAT1, and STAT3 phosphorylation & JAK1 (88) & $A D$ \\
\hline \multicolumn{4}{|c|}{ Immune dysregulation with early onset Colitis } \\
\hline IL-10 deficiency & No FC assay available. Normal STAT3 phosphorylation in response to IL-10 & $\mathrm{IL}-10(89)$ & $A R$ \\
\hline IL-10RA deficiency & $\begin{array}{l}\text { IL-10RA expression; defective STAT3 phosphorylation in response to IL-10. Normal STAT3 } \\
\text { phosphorylation in response to IL-23 }\end{array}$ & IL-10Ra (90) & $\mathrm{AR}$ \\
\hline IL-10RB deficiency & $\begin{array}{l}\text { IL-10RB expression; defective STAT3 phosphorylation in response to IL-10. Normal STAT3 } \\
\text { phosphorylation in response to IL-23 }\end{array}$ & IL-10Rb (90) & $\mathrm{AR}$ \\
\hline
\end{tabular}

Diseases are classified as reported by the 2017 IUIS phenotypic classification for PIDs (24). AD, Autosomal dominant; ALPS-FAS, Autoimmune lymphoproliferative syndrome-Fas cell surface death receptor; ALPS-FASLG, Autoimmune lymphoproliferative syndrome FAS ligand gene; APECED, Autoimmune polyendocrinopathy candidiasis ectodermal dystrophy; AR, Autosomal recessive; BACH2, BTB Domain And CNC Homolog 2; CASP8, cysteine-aspartic acid protease 8;CASP10, cysteine-aspartic acid protease 10; CD25 or IL2RA, Interleukin 2 Receptor A; CTLA4, cytotoxic T-Iymphocyte-associated Protein 4; DN, double negative; FADD, Fas Associated Via Death Domain; IL-10, Interleukin-10; IL-10Ra, Interleukin-10 Receptor alpha; IL-1ORb, Interleukin-10 Receptor beta; IPEX, Immune dysregulation; polyendocrinopathy; enteropathy; XL, X-linked; JAK1, Janus Kinase 1; LRBA, LPS Responsive Beige-Like Anchor Protein; NFAT5, Nuclear Factor Of Activated T Cells 5; STAT3, signal transducer and activator of transcription 3; TPP2, Tripeptidyl Peptidase 2.

beads stimulation $(49,109,112,121)$. This degranulation assay allows the differentiation between primary and secondary HLH. The latter express CD107a normally upon cell activation (49). Furthermore, as elegantly reported by Bryceson et al. (49), the analysis of $\mathrm{CD} 107$ a expression by flow cytometry has the advantage of being a sensitive assay even when patients receive immunosuppressive therapy or have very low numbers of T/NK cells. Detailed methodological information about the detection of $\mathrm{T}$ and NK cell degranulation by flow cytometry can be found elsewhere $(36,122)$.

\section{Familial Hemophagocytic Lymphohistiocytosis (FHL) Syndromes}

FHL is a life-threatening autosomal-recessive inherited hyperinflammatory syndrome that usually develops within the first 2 years of age (56). FHL syndromes are caused by mutations in perforin-1 (PRF1), designated as FLH2, accounting for 30$50 \%$ of known cases $(105,108)$, or proteins involved in perforin secretion: protein unc-13 homolog D (UNC13D) (56), Syntaxin11 (STX11) (57), and Syntaxin Binding Protein 2 (STXBP2) 


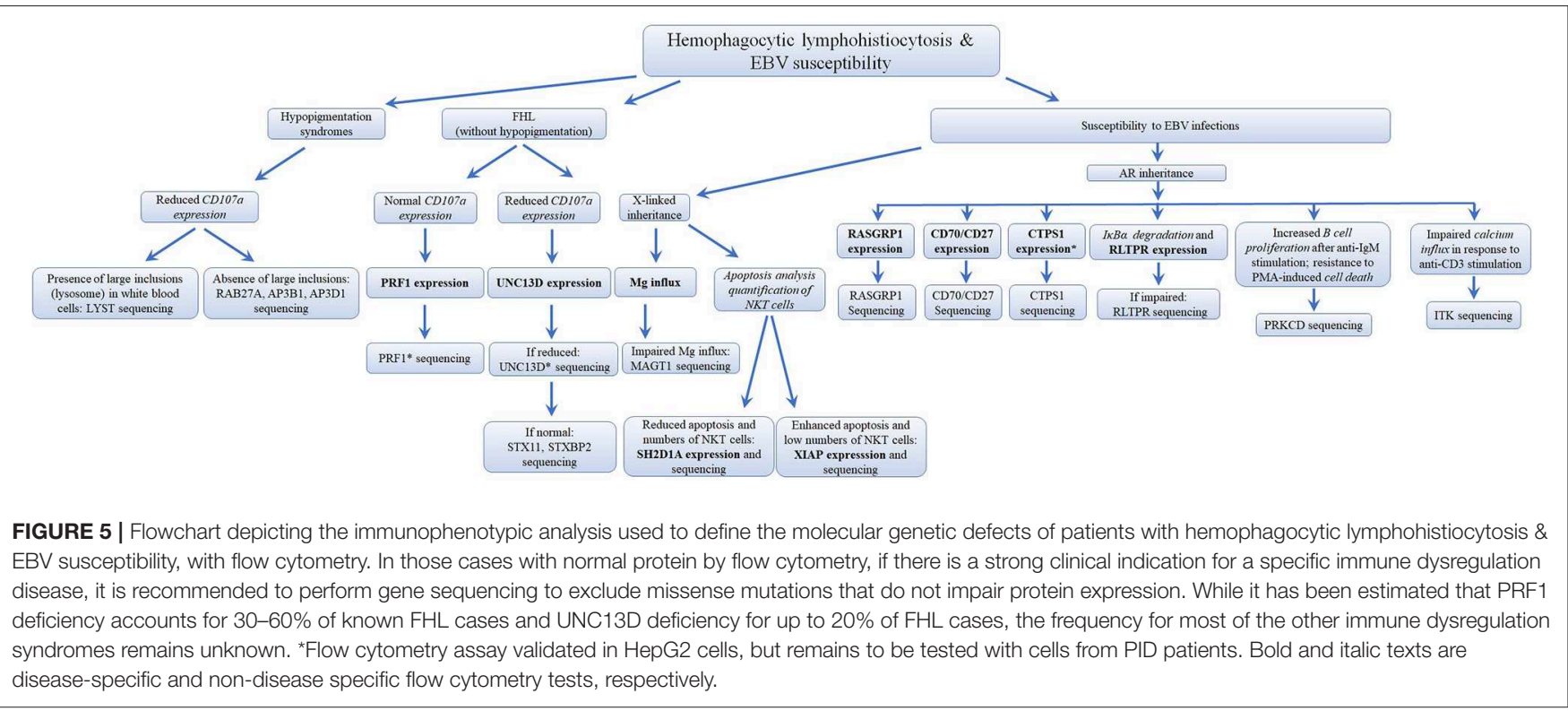

(58), known as FHL3, FHL4, and FHL5, respectively. The gene responsible for FHL1 has not yet been identified (107).

Defective perforin expression by NK cells $\left(\mathrm{CD} 3^{-} \mathrm{CD} 56^{+} \mathrm{CD}_{16}{ }^{+}\right)$and cytotoxic $\mathrm{T}$ lymphocytes $\left(\mathrm{CD}^{+} \mathrm{CD}^{+}\right)$can be detected by flow cytometry and has been used as a screening approach for FHL2 (34). Likewise, patients with UNC13D deficiency, which accounts for up to $20 \%$ of FHL cases, can be identified by decreased UNC13D expression using flow cytometry. Usually, UNC13D expression is assessed on NK cells and T lymphocytes. Since patients with UNC13D deficiency frequently present with significantly reduced leukocyte counts (pancytopenia), UNC13D expression can instead be analyzed on platelets $\left(\mathrm{CD} 41 \mathrm{a}^{+}\right)(34,105,123)$, since platelets express UNC13D more abundantly than peripheral blood leukocytes (105).

There is no specific or commercially available antibody for flow cytometry to screen patients with STX11 and STXBP2 deficiencies. Therefore, these two deficiencies have been identified indirectly by measuring CD107a expression, or by the exclusion of defective PRF1 and UNC13D expression. While cells from patients with FHL3-5 present reduced CD107a expression on the surface of NK cells and CTLs, CD107a expression is normal in subjects with PRF-1 deficiency $(49,58,123)$. This phenomenon is explained by the fact that perforin constitutes part of the lytic granule content, but in contrast to UNC13D, STX11, and STXBP2, it is not essential for the transport of secretory lysosome-related organelles $(55,58,106,107,124,125)$.

\section{Susceptibility to EBV Infection}

More than $90 \%$ of the global population are EBV-seropositive, with the majority being asymptomatic or manifesting a selflimiting disease (126). Patients with inborn errors of immunity that result in susceptibility to EBV may develop severe or fatal mononucleosis, B cell lymphoma, lymphoproliferative disease, or HLH $(67,127-129)$. Mutations in at least 11 genes (four of them with EBV-associated $H L H$ ) are known to cause increased susceptibility to EBV (24), demonstrating the non-redundant role of signaling pathways that generate EBV-specific immunity, and the pivotal role of continuous immune surveillance to ensure virus-host homeostasis $(129,130)$. The signaling pathways and outcomes involved in the immunopathogenesis of severe EBV infections (129) are summarized in Figure 4.

Notably, T cell proliferation by patients with susceptibility to EBV can be reduced, normal or even increased (Table 3); however, some subjects belonging to the same PID subgroup may display variable proliferation results where some patients with CTPS1 $(65,131)$ and $\operatorname{CD} 27(74,134)$ deficiencies have reduced $\mathrm{T}$ cell proliferation and others do not. Moreover, the abnormal proliferative responses might be stimulus dependent. For instance, patients with ITK deficiency may demonstrate reduced $\mathrm{T}$ cell proliferation in response to $\mathrm{CD} 3 / \mathrm{CD} 28$ stimulation, but normal proliferation in response to PHA stimulation (132). Therefore, in addition to be a non-specific assay to screen different PIDs, the analysis of $\mathrm{T}$ cell proliferation from patients with susceptibility to EBV needs to be carefully scrutinized as a screening flow cytometry tool to direct the definitive diagnosis of these PIDs.

\section{RASGRP1 Deficiency}

RAS guanyl-releasing protein 1 (RASGRP1) is a guanine nucleotide exchange factor and activator of the RAS-MAPK pathway initiated by diacylglycerol following TCR signaling (129). Mutations in RASGRP1 have been found in patients with a combined immunodeficiency (a ALPS-like disease) (59) presenting with recurrent respiratory infections in association with EBV-induced lymphoproliferative disease, chronic lymphadenopathy, hepatosplenomegaly, autoimmune hemolytic anemia, and immune thrombocytopenia (59-63). In addition to its availability as a screening tool to establish the diagnosis of RASGRP1 deficiency (59), flow cytometry has been 
TABLE 3 | T cell proliferation response of PIDs with susceptibility to EBV.

\begin{tabular}{lllllllllll}
\hline \multicolumn{10}{c}{ Susceptibility to EBV } \\
\hline Deficiency & RASGRP1 & CD70 & CTPS1 & RLTPR & ITK & MAGT1 & PRKCD & XLP1 & XIAP & CD27 \\
$\begin{array}{l}\text { T cell proliferation } \\
\text { References }\end{array}$ & Reduced & Reduced & Reduced & Reduced & Reduced & Reduced & Normal & Increased & Reduced & Reduced \\
& $(60)$ & $(64)$ & $(65,131)$ & $(66)$ & $(132)$ & $(68)$ & $(70)$ & $(133)$ & $(73)$ & $(74,134)$ \\
\hline
\end{tabular}

widely applied to evaluate functional defects resulting from RASGRP1 mutations. For instance, this approach can be used to detect reduced $\mathrm{T}$ cell expansion by a cell proliferation kit (e.g., CellTrace), impaired T cell activation by CD69 staining, and markedly reduced phosphorylation of ERK. Diminished intracellular expression of active caspase 3 in lymphocytes associated with reduced apoptosis using annexin $\mathrm{V}(\mathrm{AV})$ and propidium iodide (PI) staining has been observed (59-61).

\section{CD70/CD27 Deficiencies}

Disorders of T cell co-signaling pathways such as those caused by deficiencies in CD40L, SAP, OX40, or CD70/CD27 highlight the critical role of co-stimulation for host defense (135-137). Patients with mutations affecting the co-stimulatory molecules CD70 and CD27 (Figure 4), which are expressed on the surface of T, B and NK cells (138-140) present with similar clinical phenotypes. These patients exhibit impaired effector $\mathrm{CD}^{+} \mathrm{T}$ cell generation, hypogammaglobulinemia, lack of memory B cells, and reduced cytolytic and proliferative responses of $\mathrm{T}$ cells resulting in chronic EBV infections (EBV-associated lymphoproliferation, EBV-associated HLH, and B cell lymphoma). Additionally, affected patients might develop severe forms of other viral infections including influenza, herpesviruses (e.g., varicellazoster virus), and cytomegalovirus (CMV) (64, 74, 134, 141-143). Cell-surface expression of both CD70 and CD27 are assessed by flow cytometry using specific monoclonal antibodies. Similar to other combined deficiencies, it is possible that a mutated nonfunctional protein is expressed on the cell surface $(144,145)$ in which case it is possible to analyse the ability of a CD27Fc fusion protein that binds to CD70, by flow cytometry (64).

\section{RLTPR Deficiency}

The RLTPR (RGD motif, leucine-rich repeats, tropomodulin domain, and proline-rich containing) is a scaffold protein that bridges CD28 located on the cell-surface to the cytosolic adaptor called Caspase Recruitment Domain Family Member 11 (CARD11), enabling proper activation of the TCR-induced NF- $\kappa \mathrm{B}$ signaling pathway $(146,147)$. Although human CD28 deficiency has not yet been characterized, RLTPR deficiency was recently reported as an autosomal recessive combined immunodeficiency highlighting the critical role of the CD28 pathway for T- and B-cell activation (66). RLTPR-deficient patients present with low numbers of memory $\mathrm{CD} 4^{+} \mathrm{T}$ cells, reduced numbers of $\mathrm{T}$ helper (Th)1, Th17, and $\mathrm{T}$ follicular helper cells, as well as reduced memory B cells, and show poor antibody responses to vaccines $(67,148)$. RLTPR deficiency causes susceptibility to a variety of pathogens, including bacteria, fungi, and viruses (e.g., EBV). RLTPR expression can be detected by flow cytometry in adaptive (B and T lymphocytes) and innate (monocytes and dendritic cells) immune cells. Moreover, NF$\kappa \mathrm{B}$ signaling defects $(149,150)$ in $\mathrm{CD}^{+}$and $\mathrm{CD}^{+}{ }^{+} \mathrm{T}$ cells from patients with RLTPR mutations have been characterized by flow cytometry, primarily manifested by reduced NF- $\kappa$ B P65 phosphorylation and I $\mathrm{B} \alpha$ degradation following anti-CD28 stimulation (66). In this context, there is a debatable paradigm that CD28 co-stimulation is not necessary for the activation of memory T cells. In agreement, flow cytometric analysis of T cell proliferation has shown that the lack of RLTPR only impairs the proliferation of naïve, but not memory $T$ cells (66). Flow cytometric analysis also points out a critical role of RLTPR in NK cells, since their degranulation capacity is impaired after K562 stimulation, depicted by reduced CD107a expression (151).

\section{CTPS1 Deficiency}

The cytidine nucleotide triphosphate synthase 1 (CTPS1) is a molecule involved in DNA synthesis in lymphocytes (152) and therefore plays a central role in lymphocyte proliferation (65, 131). Loss-of-function homozygous mutations in CTPS1 cause a combined immunodeficiency characterized by the impaired capacity of activated $\mathrm{T}$ and $\mathrm{B}$ cells to proliferate in response to antigen receptor-mediated activation (65). CTPS1-deficient patients are susceptible to life-threatening bacterial and viral infections, including those caused by EBV (e.g., EBV-related Bcell non-Hodgkin lymphoma). Flow cytometry has only been used to evaluate $\mathrm{T}$ lymphocyte proliferation in response to an anti-CD3 antibody or anti-CD3/CD28 coated beads, as well as $B$ cells in response to anti-BCR plus $\mathrm{CpG}$, which were found to be defective (65). However, patients with normal lymphoproliferative response have also been reported (131). There is no anti-CTPS1 fluorochrome-conjugated antibody commercially available. Therefore, CTPS1 expression is analyzed by western blot (65). CTPS1 expression by flow cytometry has been validated in HepG2 cells through incubation of primary unconjugated antibody followed by a dye-conjugated secondary antibody staining (153). This staining strategy represents a potential approach to screen patients with CTPS1 deficiency by flow cytometry.

\section{ITK Deficiency}

Mutations in the IL-2-inducible T cell kinase (ITK) causes a lifethreatening syndrome of immune dysregulation and therapyresistant EBV-associated lymphoproliferative disease (154-156). ITK is a signaling molecule located proximal to the TCR (Figure 4). ITK is expressed in thymocytes and peripheral $\mathrm{T}$ cells, regulating the thresholds of TCR signaling and specific development of $\mathrm{CD}^{+} \mathrm{T}$ cells (131). Flow cytometry analysis 
has shown that ITK deficient patients exhibit a reduced TCRmediated calcium flux in T cells (67) and an absence of NKT cells as determined by the lack of TCR V $\beta 11$ and TCR V $\alpha 24$ double-positive cells (156).

\section{MAGT1 Deficiency}

In addition to its essential role as a co-factor for nucleic acids and metabolic enzymes $(157,158)$, a critical role of magnesium ion $\left(\mathrm{Mg}^{2+}\right)$ in immune responses has been demonstrated by disease-causing mutations in the magnesium transporter 1 gene (MAGT1). Li et al. (68) reported $\mathrm{Mg}^{2+}$ as an intracellular second messenger following TCR activation in patients with an X-linked inborn error of immunity characterized by $\mathrm{CD} 4^{+} \mathrm{T}$ cell lymphopenia, severe chronic viral infections (e.g., EBV infection associated with lymphoproliferative disease or lymphoma), and defective $\mathrm{T}$ lymphocyte activation. Flow cytometry was used by the authors to characterize several immunological defects, but not the expression of MAGT1, which was investigated by Western blots. A reduced CD69 expression by $\mathrm{CD}^{+} \mathrm{T}$ cells after anti-CD3 stimulation was identified, while the response to phorbol 12-myristate 13-acetate (PMA) plus Ionomycin was normal, thus suggesting a specific defective TCR signaling that was confirmed by impaired NF$\kappa \mathrm{B}$ and NFAT nuclear translocation using confocal microscopy. Reduced levels of naïve $\mathrm{CD} 4^{+} \mathrm{T}$ cells $\left(\mathrm{CD} 27^{+}, \mathrm{CD}_{4} 5 \mathrm{RO}^{-}\right)$ expressing CD31, a cell surface marker of naive TREC-rich $\mathrm{T}$ cells, suggest a diminished thymic output (159-161). Kinetic analysis by flow cytometry also revealed abrogation of TCRinduced $\mathrm{Mg}^{2+}$ influx, which can be detected by the $\mathrm{Mg}^{2+}$. specific fluorescent probe, MagFluo4 (68). Another immunologic feature of the disease is the impaired cytotoxic function of NK and $\mathrm{CD}^{+} \mathrm{T}$ cells. Chaigne-Delalande et al. (162) elegantly demonstrated that decreased intracellular free $\mathrm{Mg}^{2+}$ causes impaired expression of the natural killer activating receptor NKG2D in NK and $\mathrm{CD}^{+}{ }^{+} \mathrm{T}$ cells, impairing cytolytic responses against EBV.

\section{PRKCD Deficiency}

Protein kinase C delta (PKC $)$ (69-71, 163) belongs to a family of at least 11 serine/threonine kinase members involved in several pathological conditions $(164,165)$. Mutations in this gene cause a monogenic disease that presents either as SLE-like disease or as autoimmune lymphoproliferative syndrome (ALPS)-like disorder. PKC $\delta$ deficiency is associated with uncontrolled lymphoproliferation and chronic EBV infection. Immunologically, human PKC $\delta$ deficiency results in a $\mathrm{B}$ cell disorder characterized by $\mathrm{B}$ cell resistance to apoptosis, B cell hyperproliferation, increased production of autoantibodies, and decreased numbers of memory $\mathrm{B}$ cells (69-71, 163). A similar phenotype has been identified in PKC $\delta$ knockout mice (166-168), demonstrating the essential role of PKC $\delta$ in B cell tolerance. Flow cytometry applications to investigate this disease are designed to demonstrate increased B cell proliferation after anti-IgM stimulation, resistance to PMA-induced cell death (70), and the almost absence of CD27 expression on B cells (69), i.e., absence of memory cells.

\section{X-Linked Lymphoproliferative Syndromes}

$\mathrm{X}$-linked lymphoproliferative syndrome (XLP) is a PID that presents with severe or fatal EBV infection, acquired hypogammaglobulinemia, malignant lymphoma, and HLH $(72,169)$. Most XLP cases are due to mutations in the SH2 domain protein 1A (SH2D1A) gene (XLP type 1), which encodes the signaling lymphocytic activation molecule (SLAM)associated protein (SAP) (72). SAP is an adapter molecule that controls several signaling pathways involved in lymphocyte activation, proliferation, cytotoxicity, and also promotion of apoptosis [Figure 4; (170-172)]. The defect in antibody production exhibited by SH2D1A-deficient patients probably arise from impaired $\mathrm{CD} 4^{+} \mathrm{T}$ cell interaction with $\mathrm{B}$ cells rather than an intrinsic B cell failure $(169,173)$.

Mutations in the gene encoding the X-linked inhibitor of apoptosis (XIAP), which inhibits caspase- $3,-7$, and -9 by direct binding (174), are responsible for XLP type 2 syndrome (73).The clinical phenotype and the disease pathogenesis have been reviewed and compared in detail elsewhere (129, 172, $175,176)$. Flow cytometry can be used to evaluate apoptosis, in order to distinguish both XLP forms. Due to the distinct physiological roles of SH2D1A and XIAP, enhanced apoptosis of T lymphocytes is observed in patients with XIAP-deficiency, while the absence of SAP in SH2D1A deficiency is consistently associated with impaired cell apoptosis $(133,170,172)$. This might explain why cytopenia is common in XIAP but not in SH2D1A deficiency (129). The EBV-associated immune dysregulation in XIAP deficiency might, in part, be due to the combination of an intrinsic exacerbated proliferation of immune cells plus the incapacity to respond to EBV. The lymphoproliferative disease reported in SH2D1A deficiency seems to be more the consequence of extrinsic and constant stimulation induced by EBV that cannot be properly controlled. For both XLP forms, flow cytometry to test intracellular testing for SAP and XIAP protein expression is available [Figure 6; (34)]. In addition, flow cytometric testing has demonstrated that the absence of SAP or XIAP proteins results in reduced numbers of circulating NKT (V $\alpha 24 \mathrm{TCR}^{+} /{\left.\mathrm{V} \beta 11 \mathrm{TCR}^{+}\right)}$cells (73).

\section{SYNDROMES WITH AUTOIMMUNITY}

The second major group of diseases of immune dysregulation named "Syndromes with Autoimmunity and Others," is subdivided based on the increased percentage of $\mathrm{CD} 4^{-} \mathrm{CD} 8^{-} \mathrm{TCR} \alpha / \beta$ (double negative $[\mathrm{DN}] \mathrm{T}$ cells), on Treg defects, and the development of colitis (24). The 21 diseasecausing genes belonging to this group are represented in Figure 7 as well as a summarized guideline (Figure 8) which describes the flow cytometric assays required to diagnose patients with syndromes that include autoimmunity.

\section{Syndromes Associated With an Increased Percentage of CD4 ${ }^{-}$CD $8^{-}$TCR $\alpha / \beta$ Cells} Autoimmune Lymphoproliferative Syndromes (ALPS) TCR $\alpha / \beta$ DN T cells are useful biomarkers, frequently elevated in children with autoimmune lymphoproliferative syndromes 


\section{Healthy Controls}
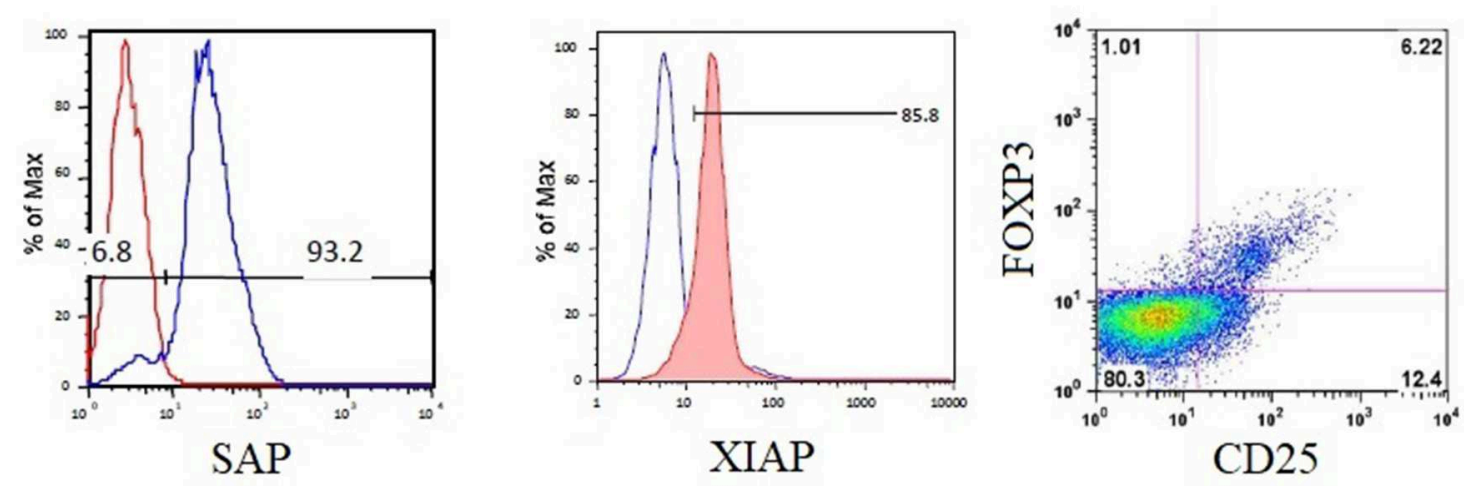

XLP1

XLP2

IPEX

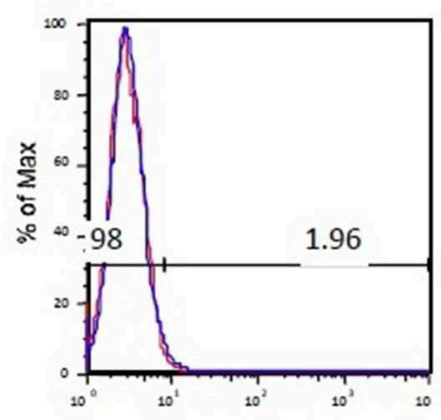

SAP
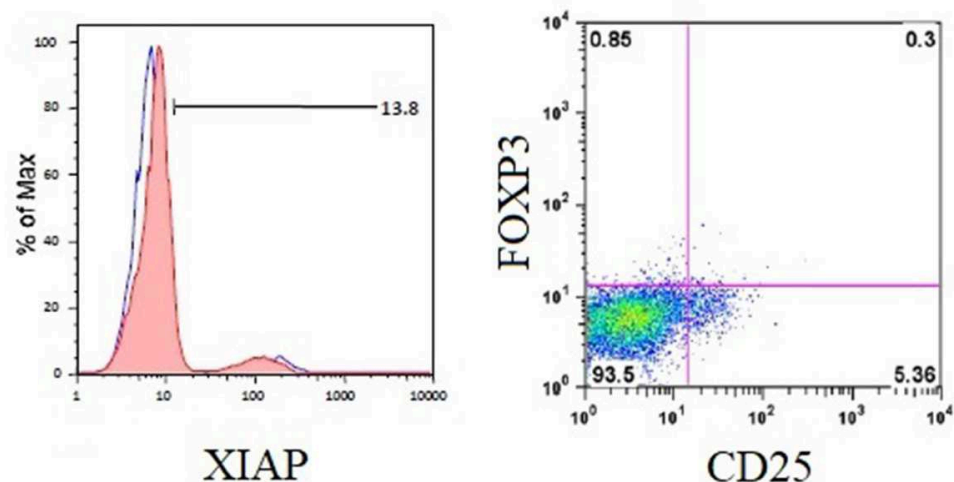

FIGURE 6 | Disease-specific flow cytometry tests for PIDs with immune dysregulation. The histograms show the normal expression of SAP and XIAP from healthy control lymphocytes (upper panels) compared with the absent expression of SAP and XIAP in lymphocytes from patients with X-linked lymphoproliferative syndrome type 1 (XLP1) and XLP2 (lower panels), respectively. The dot plot exhibits the absence of nuclear forkhead box P3 (FOXP3) expression in CD4 ${ }^{+}$CD25 ${ }^{+}$regulatory $T$ cells from patient PBMCs with immune dysregulation, polyendocrinopathy, enteropathy, X-linked inheritance syndrome (IPEX) (bottom right panel) compared with healthy control PBMCs (top right panel).

(ALPS) (179). The immunological functions of these cells have been reviewed in detail elsewhere (180). However, their precise role in the pathogenesis of autoimmune diseases is not well understood (179). ALPS is caused by mutations in five different genes: FAS, FASL, FADD, CASP8, and CASP10. The interaction between Fas (CD95) and Fas ligand or FasL (CD178), both expressed by activated $\mathrm{T}$ lymphocytes (the former also present on other cell types), triggers the formation of a deathinducing signaling complex $(181,182)$. This process involves the recruitment of Fas-associated death domain (FADD), cysteineaspartic acid protease 8 (CASP8), and CASP10, initiating a cascade of signaling events that result in apoptotic cell death (183). This process regulates lymphocyte life span and promotes the elimination of autoreactive lymphocytes (Figure 7). The syndromes caused by mutations in these five genes have been classified by the National Institutes of Health (NIH) (177) as ALPS-FAS cell surface death receptor (the most frequent) (75), ALPS-FASL (76), ALPS-Caspase 8 (77), ALPS-Caspase 10 (78), and the FADD-deficiency (79). These disorders generally present as lymphadenopathy, splenomegaly, and autoimmune manifestations such as autoimmune hemolytic anemia, and severe recurrent thrombocytopenia $(75-79,184)$. Laboratory findings also include polyclonal hypergammaglobulinaemia, $\mathrm{T}$ lymphocyte apoptosis defect, and increased percentages of TCR $\alpha / \beta$ DN T cells (177).

Flow cytometry analysis demonstrates defective $\mathrm{T}$ cell apoptosis in response to anti-Fas antibody, recombinant FasL, or after phytohaemagglutinin (PHA)-/IL-2 stimulation by using FasT Kill assays or AV/PI or 7-AAD-staining. The technique of detecting increased percentages of TCR $\alpha / \beta$ DN T cells within peripheral blood mononuclear cells (PBMCs) is well established $(76,185,186)$. Moreover, protein expression of FAS (187) and FASL (186) (both after T-cell blast generation by PHA plus IL-2) by flow cytometry is available to investigate ALPS-FAS and ALPS-FASL, respectively. Although the other ALPS forms (due to FADD (79), CASP8, or CASP10 deficiency) have not yet been studied by flow cytometry due to the unavailability of specific fluorescent conjugated antibodies, mutations in the FAS 


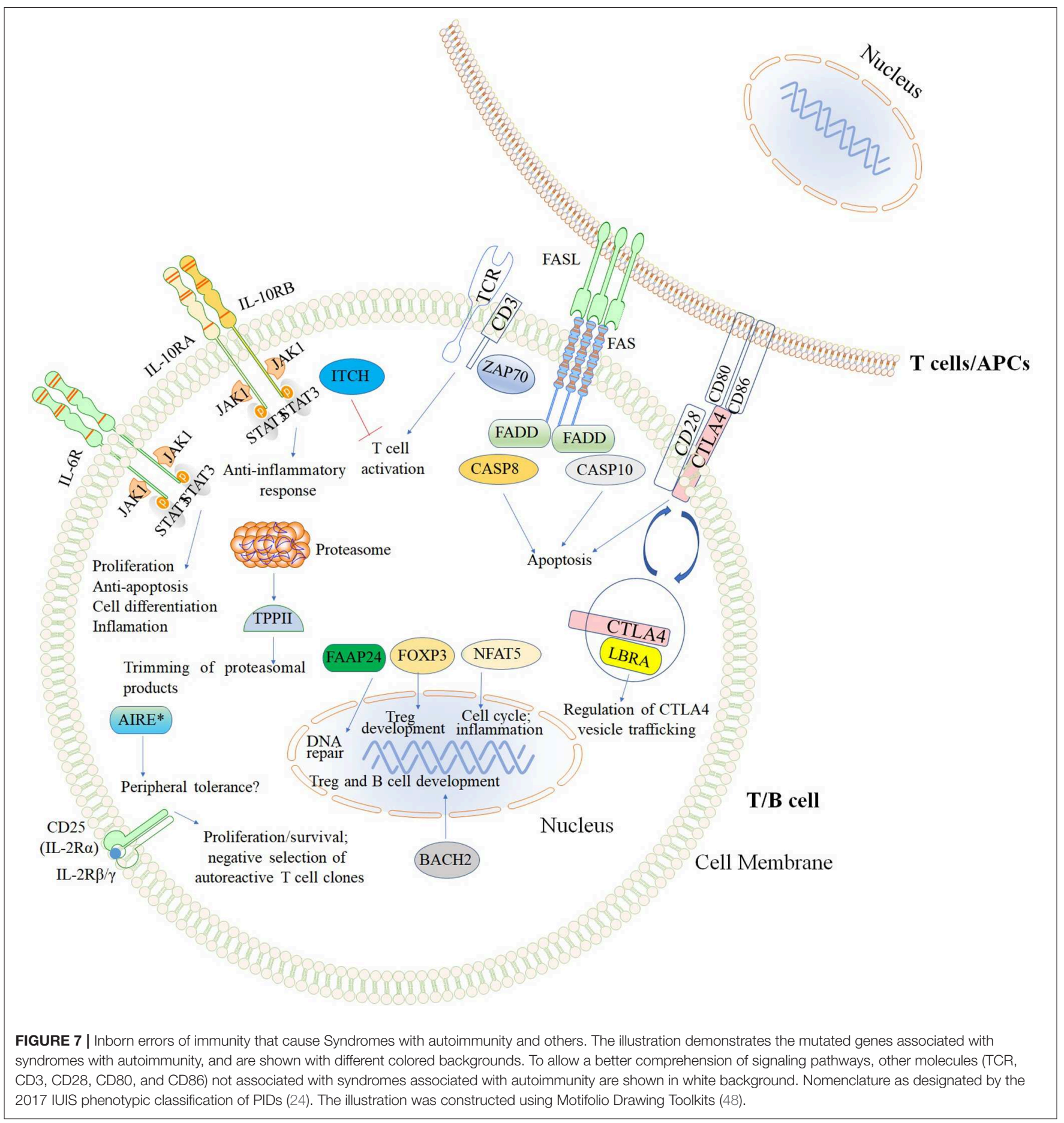

receptor is the most frequent disease form of ALPS found in $\sim 70 \%$ of genetically defined ALPS $(177,178)$ thereby making flow cytometry an essential screening tool for patients suspected to have ALPS.

\section{STAT3 Gain-of-function Mutations}

While heterozygous germline inactivating mutations in the signal transducer and activator of transcription 3 (STAT3) with dominant negative effect cause autosomal dominant hyper IgE syndrome (188), heterozygous gain-of-function (GOF) mutations in STAT3 result in an ALPS-like phenotype (81). Patients can develop early-onset poly-autoimmunity (e.g., type 1 diabetes), autoimmune hypothyroidism, enteropathy, pulmonary disease, cytopenias, arthritis, short stature, myelodysplastic syndrome, aplastic anemia, and lymphocytic leukemia $(81,189,190)$. Increased percentages of TCR $\alpha \beta^{+}$-DN 


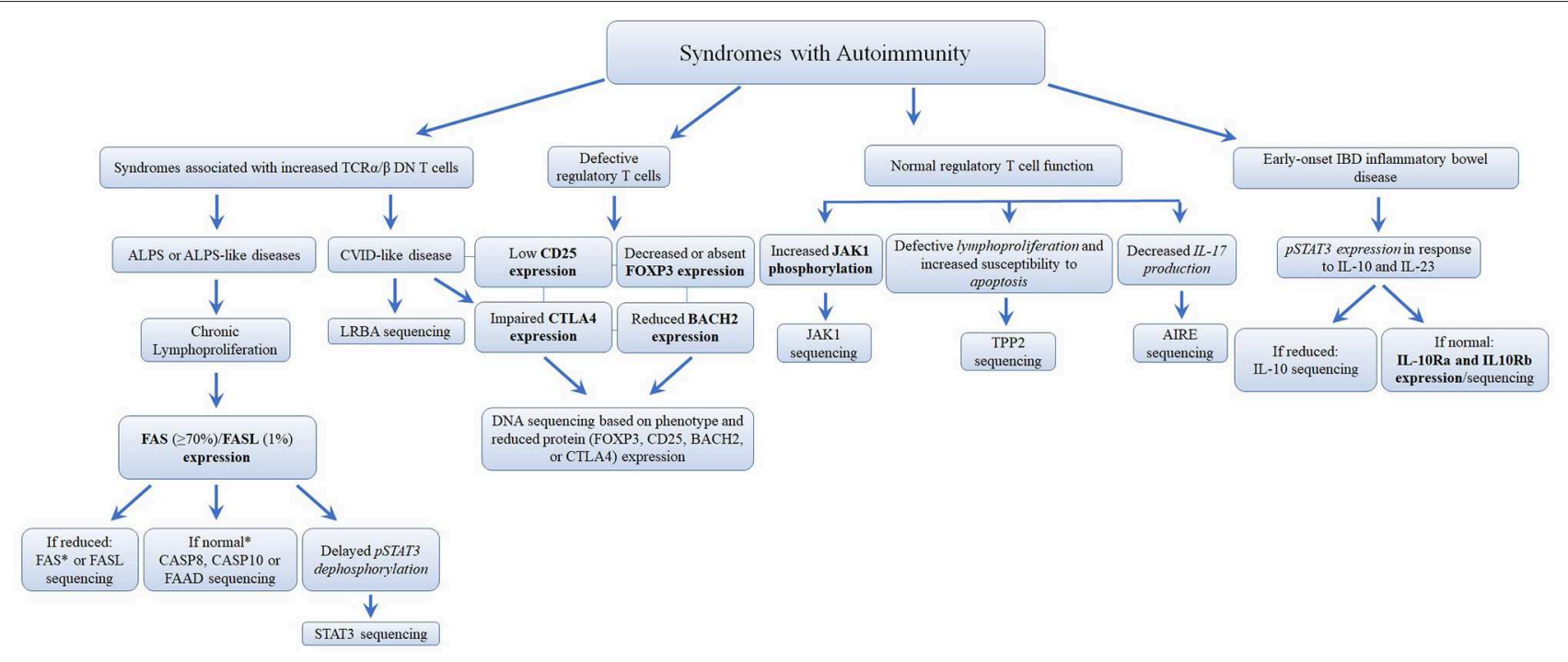

FIGURE 8 | Flowchart depicting the recommended immunophenotypic analysis used to define the molecular genetic defects of patients with immunodeficiency syndromes with Autoimmunity. In those cases with normal protein by flow cytometry, if there is a strong clinical indication for a specific immune dysregulation disease, it is recommended to perform gene sequencing to exclude missense mutations that do not impair protein expression. It is estimated that mutations in the FAS receptor are the most frequent pathology of ALPS ( $\cong 70 \%$ of genetically defined ALPS) $(177,178)$. However, the frequency of other immune dysregulation syndromes remains unknown. Bold and italic texts are disease-specific and non-disease specific flow cytometry tests, respectively.

T cells are occasionally identified (189). So far, STAT3 GOF mutations have been shown to enhance transcriptional activity and delay dephosphorylation of STAT3, without inducing constitutive phosphorylation as shown by flow cytometry studies. In agreement with the involvement of STAT3 in the inhibition of Tregs $(191,192)$ and enhancement of Th17 cell differentiation (193), flow cytometry has also shown increased Th17 levels while the $\mathrm{FOXP} 3^{+} \mathrm{CD} 25^{+}$Treg population is reduced and the expression of CD25 (IL2RA) is decreased in patients with STAT3 GOF mutations (189). Due to its activity as a repressor of FAS-FASL activity, decreased FASL-induced apoptosis has been observed (190).

\section{LRBA Deficiency}

Mutations in the lipopolysaccharide responsive beige-like anchor protein (LRBA) gene cause a common variable immunodeficiency (CVID)-like disease with predominant antibody deficiency (hypogammaglobulinemia) and autoimmunity (e.g., autoimmune hemolytic anemia as well as atrophic gastritis with autoantibodies against intrinsic factor, autoimmune enteropathy, hypothyroidism, myasthenia gravis, polyarthritis), and inflammatory bowel disease (80, 194, 195). The phenotype of LRBA deficiency has been well-characterized elsewhere (196). LRBA is highly expressed in immune cells such as $\mathrm{T}$ and $\mathrm{B}$ cells (80). The application of flow cytometry to screen patients with LRBA deficiency has been recently developed (197) as well as its application to evaluate several immunopathological mechanisms of this disease. More than $70 \%$ of the LRBA-deficient patients have reduced levels of Tregs (196) $\left(\mathrm{CD}^{+} \mathrm{CD}^{2} 5^{+} \mathrm{FOXP}^{+}\right)$, which may be related to the low surface expression of cytotoxic $\mathrm{T}$ lymphocyte-associated antigen 4 (CTLA4 or CD152) (198). CTLA4 is a cell surface molecule required for the proper suppressive function of Tregs (199-201). The reduced CTLA4 levels can be explained by the fact that LRBA is a regulator of CTLA4 vesicle trafficking [Figure 5; (197)]. Increased percentages of TCR $\alpha / \beta$ DN T cells have been found in up to $50 \%$ of LRBA-deficient patients (196). Several other defects associated with LRBA deficiency have been identified by flow cytometry (80). Among them are increased $\mathrm{B}$ cell apoptosis, low levels of $\mathrm{IgG}^{+} \mathrm{IgA}^{+} \mathrm{CD} 27^{+}$switched-memory $\mathrm{B}$ cells, reduced $\mathrm{B}$ cell proliferation, and impaired activation (as measured by CD138 expression).

\section{Defective Regulatory T Cells}

The next two subgroups of Syndromes with Autoimmunity are based on the presence or absence of Treg defects (24). Tregs play a central role in peripheral immune tolerance, which controls the response of mature $\mathrm{B}$ and $\mathrm{T}$ cells that egressed from the primary lymphoid organs (202-204). Several autoimmune diseases have demonstrated the essential role of Tregs (202, 205), whose development is orchestrated by the transcription factor FOXP3.

\section{Immune Dysregulation Due to Abnormal Tregs IPEX}

The immune dysregulation, polyendocrinopathy, enteropathy, $\mathrm{X}$-linked syndrome (IPEX) is caused by loss of function mutations in the FOXP3 gene (82). Clinical, immunological, and molecular features of IPEX syndrome have recently been characterized in a large cohort of patients (206). Flow cytometry of $\mathrm{CD}^{+} \mathrm{FOXP}^{+} \mathrm{CD} 25^{+}$cells is well established to screen patients suspected to have IPEX who normally have low or absent nuclear FOXP3 expression in Tregs [Figure 6; (34)]. However, 
patients with missense mutations in FOXP3 may present with normal protein expression and are not suitable for flow analysis. The identification of FOXP3 mutations is essential to differentiate patients with IPEX from those with IPEX-like syndromes caused by mutations in other immune regulatory genes (e.g., $L R B A$, CTLA4, and CD25) $(83,206)$.

\section{CD25 deficiency}

Although CD25-deficient patients display normal percentage of $\mathrm{FOXP}^{+}$cells, mutations in the CD25 gene, which encodes the high-affinity subunit IL-2 receptor alpha chain (IL-12RA) of the tripartite receptor for IL-2 (83), causes an IPEX-like syndrome. This observation is explained by the fact that CD25, which can be detected by flow cytometry, is required for the production of the immunoregulatory cytokine IL-10 by Tregs (207). This suggests that $\mathrm{CD} 25$ is required for the function but not the survival of Tregs (207). CD4 ${ }^{+}$lymphocytes are decreased in numbers, and the proliferative response following stimulation with anti-CD3, PHA, or other mitogens is diminished (208). In addition, CD25 deficiency decreases apoptosis in the thymus, impairing negative selection of autoreactive $\mathrm{T}$ cell clones, resulting in inflammation in multiple organs (208).

Flow cytometry has also defined a role of CD25 in NK cell maturation and function, as suggested by the accumulation of $\mathrm{CD} 56^{\text {bright }} \mathrm{CD} 16^{\text {high }}$ and reduced frequency of $\mathrm{CD} 56^{\text {dim }} \mathrm{CD} 16^{\text {hi }}$ NK cell in the peripheral blood as well as the expression of higher amounts of perforin and granzyme B. Increased degranulation (by increased CD107a expression) while reduced IFN- $\gamma$ production by NK cells has also been reported (209).

\section{CTLA4 deficiency}

Mutations in the inhibitory receptor CTLA4, which acts to terminate the proliferation of activated $\mathrm{T}$ cells, have recently been recognized as a monogenic cause of CVID $(210,211)$. Therefore, for diagnostic assays of CTLA4, LRBA, and BACH2, defects in these molecules need to be evaluated in parallel (Figure 7; see section BACH2 Deficiency). CTLA4 is also constitutively expressed by Tregs and functions as a key checkpoint molecule for immune tolerance $(211,212)$. Details of CTLA4 biology and immunophenotyping of CTLA4 haploinsufficiency have recently been reviewed $(213,214)$. Briefly, CTLA4 competes effectively with CD28 because of higher affinity for binding to the costimulatory molecules CD80 and CD86, which are expressed on the surface of antigen-presenting cells (215). Patients with CTLA4 haploinsufficiency develop a $\mathrm{T}$ cell hyperproliferative syndrome resulting in lymphocytic infiltration of multiple organs (e.g., brain, gastrointestinal, and lung), autoimmune thrombocytopenia, hemolytic anemia, and other cytopenias, as well as hypogammaglobulinemia $(84,210)$, and increased susceptibility for cancer (216). Decreased CTLA4 expression can be demonstrated by flow cytometry. This tool is also useful to assess the effect of different mutations on CTLA4 function, which would normally require complex assays. For instance, flow cytometry can be used to demonstrate that CTLA4 loses its ability to interact with its natural ligands (CD80 and CD86), to traffic from the intracellular compartment to the cell membrane, and to inhibit $\mathrm{T}$ cell activation by physical removal of CD80/CD86 by CTLA4-mediated trans-endocytosis $(211,217,218)$.

\section{BACH2 deficiency}

The gene encoding the BTB and CNC homology 1, basic leucine zipper transcription factor $2(\mathrm{BACH} 2)$ is involved in the maturation of $\mathrm{T}$ and $\mathrm{B}$ lymphocytes. $\mathrm{BACH} 2$ is required for class switch recombination (CSR), somatic hypermutation (SHM) of immunoglobulin genes, and generation of regulatory T cells $(219,220)$. BACH2 haploinsufficiency has recently been associated with CVID and lymphocytic colitis. Low BACH2 protein expression in $\mathrm{CD}^{+}, \mathrm{CD}^{+} \mathrm{T}$ and $\mathrm{B}$ lymphocytes can be demonstrated by flow cytometry, together with significantly decreased numbers of Foxp $3^{+}$Treg cells, increased Th1 cells, reduced $\mathrm{CD} 19^{+} \mathrm{CD} 27^{+}$memory, and low IgG class-switched $\mathrm{CD}^{2} 7^{+} \mathrm{IgG}^{+}$B cells (85).

\section{Normal Treg Function \\ APECED}

The discovery that mutations in the autoimmune regulator $(A I R E)$ gene cause the autoimmune-polyendocrinopathycandidiasis-ectodermal-dystrophy (APECED) syndrome (221) provided the novel concept that a monogenic defect can cause a systemic human autoimmune disease (86). The endocrinopathies presented by APECED patients are characterized by hypoparathyroidism, hypothyroidism, adrenal failure, gonadal failure, and autoimmune hepatitis. The ectodermal dystrophies comprise vitiligo, alopecia, keratopathy, and dystrophy of dental enamel, nails, and tympanic membranes $(86,222)$.

AIRE mediates central $\mathrm{T}$ cell tolerance by promoting the expression of thousands of tissue-specific self-antigens by medullary thymic epithelial cells (mTEC), leading to the deletion of T cells with strongly self-reactive TCR (223). Extrathymic AIRE expression has recently been reported in response to antigen and interleukin 2 stimulation in human peripheral blood cells such as $\mathrm{CD}^{+} \mathrm{T}$ cells, suggesting a role of AIRE in mature lymphocytes (224). However, there is no flow cytometry assay available to analyze AIRE expression in peripheral blood lymphocytes. To explore the expression of AIRE in $\mathrm{CD}^{+} \mathrm{T}$ cells to screen patients with APECED could improve the precise diagnosis of this disease, once the screening is currently based on the presence of the classical triad of CMC, hypoparathyroidism and adrenal insufficiency (Addison's disease) (225).

\section{Tripeptidyl-peptidase II deficiency}

Tripeptidyl peptidase II (TPPII) is a cytosolic peptidase that works downstream of proteasomes in cytosolic proteolysis by trimming proteasomal degradation products [Figure 7; (226)]. TPPII modulates several cellular processes, including antigen presentation by major histocompatibility complex (MHC) I molecules, $\mathrm{T}$ cell proliferation, and survival (87, 227). Among others, patients with TPPII deficiency develop autoimmune manifestations (e.g., immune hemolytic anemia, immune thrombocytopenia, and other cytopenias), and they are susceptible to viral infections such as CMV and severe chickenpox (87). 
Although not used to assess TPPII expression in lymphocytes for establishing the diagnosis of TPPII deficiency, flow cytometry has been broadly employed to immunophenotypes and characterize lymphocyte function in affected patients. Lymphocytes from TPPII-deficient patients express higher levels of HLA class I molecules, present a skewed Teffector memory phenotype, and have a predominant $\mathrm{CD} 8^{+} \mathrm{CD} 27^{-} \mathrm{CD} 28^{-} \mathrm{CD} 127^{-}$phenotype (87), which has been associated with enhanced effector functions and increased percentages of IFN- $\gamma$ - and IL-17- positive T cells, as well as high levels of T-bet and perforin expression. Defective lymphoproliferation and increased susceptibility to apoptosis were also characterized by flow cytometry using Carboxyfluorescein succinimidyl ester (CFSE) and AV/PI. Furthermore, the patients showed increased levels of $\mathrm{CD} 21^{\text {low }}$ cells, an autoreactive B cell population often associated with CVID and autoimmune diseases. CD2 $1^{\text {low }} \mathrm{B}$ cells are thought to have undergone activation and proliferation in vivo while exhibiting defective proliferation in response to $\mathrm{B}$ cell receptor stimulation $(228,229)$.

\section{JAK1 gain-of function}

The janus kinase 1 (JAK1) plays a central role in cytokine (e.g., interferon- $\alpha$, IFN- $\gamma$, IL-6) signaling by phosphorylating STAT proteins (e.g., STAT1, STAT2, and STAT3). STAT proteins translocate to the nucleus and activate the transcription of many genes involved in immune responses (230). A family with a JAK1 germline GOF mutation that causes a systemic immune dysregulatory disease has recently been reported. Affected patients present with severe atopic dermatitis, profound eosinophilia, and autoimmune thyroid disease. A phosphoflow cytometry assay was able to demonstrate increased JAK1 and STAT1 phosphorylation at baseline and following IFN- $\alpha$ stimulation as well as enhanced IL-6-induced STAT3 phosphorylation (88).

\section{Challenges to evaluating Treg function by flow cytometry}

Due to their relevant pathophysiological role in the maintenance of immune homeostasis, we briefly reflect on the challenges associated with evaluating Treg number and function by flow cytometry. Distinct markers have been used to characterize human $\mathrm{CD}^{+}$regulatory $\mathrm{T}$ cells since their first ex-vivo characterization in 2001 (231-233). The stable expression of the transcription factor FOXP3 represents one of the hallmarks of Tregs in both human and mice (234) and has been used to evaluate Tregs by flow cytometry, not only in PIDs with immune dysregulation but also other human diseases, including cancer (235) and diabetes (236). However, the functional characterization of human Tregs by flow cytometry still represents a challenge due to several factors; (I) FOXP3 can also be transiently expressed by activated $\mathrm{CD} 4^{+} \mathrm{T}$ cells $(237$, 238); (II) FOXP3 evaluation requires the permeabilization of the nucleus membrane thereby impeding the possibility of FACSsorting; (III) Circulating Tregs represent a very low frequency of the blood composition (representing 10\% of the $\mathrm{CD} 4^{+} \mathrm{T}$ cell compartment) and therefore a large number of PBMCs are required for adequate analysis. (IV) Classic Treg definition requires the ex-vivo evaluation of their suppressive capability.
Phenotypically, the evaluation of Tregs goes beyond the expression of FOXP3 in $\mathrm{CD} 4{ }^{+} \mathrm{T}$ cells, requiring the combination of distinct surface markers. In order to detect the high expression of the alpha chain of the IL-2 receptor $(\mathrm{CD} 25)(232,233)$, flow cytometric panels have shown that Treg cells exhibit low expression of both CD45RA (239) and IL-7 alpha receptor (CD127) $(240,241)$. Recent works have also shown that Tregs from tissues might express high levels of activation markers such as the coinhibitory receptor T cell Ig and ITIM domain (TIGIT) (242), the inducible T-cell co-stimulator (ICOS) (243), and the ectonucleotidase CD39 (244-246), which could be used for further ex-vivo isolation and characterization.

Another challenge for the laboratorial evaluation of Tregs consist of the low frequency of these cells in peripheral blood, which limits adequate functional assessment of these cells. To overcome this limitation, in vitro strategies for Treg expansion may include an initial cell enrichment step by selecting $\mathrm{T}$ cells, phenotypically characterized by $\mathrm{CD} 4^{+} \mathrm{CD} 25^{\text {high }} \mathrm{CD} 127^{\text {low }}$ expression, that will subsequently be subjected to cell culture in the presence of IL-2, rapamycin or TCR-stimulation (e.g., antiCD3 or APCs) (247-249). These strategies may be considered to achieve the number of cells required for screening or classical suppression assays using cells from patients with PIDs and immune dysregulation. In this context, Tregs are co-cultured and proliferated with conventional $\mathrm{CD} 4^{+} \mathrm{T}$ cells or $\mathrm{CD} 8^{+} \mathrm{T}$ cells under polyclonal stimulation followed by assessing suppression of proliferation with fluorescent-labeling methods. The ratios of Tregs to target cells, duration of co-culture and readout need to be adapted to each set of assays, considering variation of donors, cell viability and the sensitivity of the suppression method (250).

\section{Immune Dysregulation With Early Onset Colitis}

\section{IL-10, IL-10Ra, and IL-10Rb Deficiencies}

Interleukin $10(I L-10)$ is an important anti-inflammatory cytokine produced by cells like APCs. Early-onset (within the first months of life) of severe inflammatory bowel disease (EOIBD), i.e., Crohn's disease and ulcerative colitis (UC), can be caused by IL-10 and IL10- receptor deficiencies $(89,90,251)$. The expression of both IL-10 receptor alpha (IL-10RA) and IL-10 receptor beta (IL1ORB) can be assessed by flow cytometry (90). Of note, IL-10 binds to its receptor, leading to the activation of the JAK1-STAT3 pathway [Figure 9A; (252)]. Normal or defective IL-10-induced phosphorylation of STAT3 in T cells has been evaluated by flow cytometry to distinguish patients with EO-IBD due to IL-10 or IL-10R deficiencies (Figure 9B). Recombinant IL6 or IL-23 are used in parallel with IL-10 as stimuli to distinguish the specificity of IL-10 or IL10R deficiencies.

\section{CONCLUSION AND FUTURE PERSPECTIVES}

Since the identification of the specific mutation is the definitive approach for a specific molecular diagnosis, flow cytometry represents an extremely useful and versatile tool to effectively and rapidly evaluate patients with PIDs at relatively low costs (3235). Of note, most of the other PIDs associated with immune 

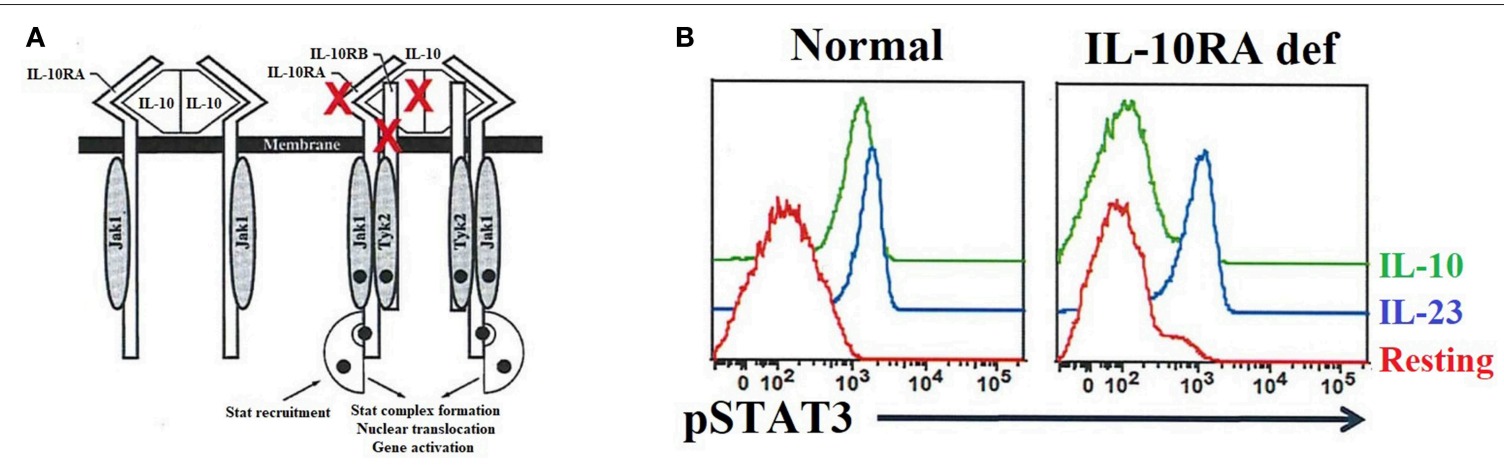

FIGURE 9 | IL-10 and IL-10 receptor deficiencies and the relevant role of flow cytometry analysis for precise diagnosis. (A) The interaction between IL-10 and its receptor (left side) as well as the downstream signaling events (right side) are exhibited. The red X highlights the IL-10 and IL-10 receptors (IL-10RA/B) that if mutated cause immune dysregulation with early onset colitis. (B) Flow cytometric histograms from a healthy control and an IL-10RA deficient patient, in resting or after IL-23 or IL-10 stimulation, illustrating the importance of flow cytometric application for functional assessment of inborn errors of immunity.

dysregulation (Figure 3) seem to be rare diseases. This current landscape is also influenced by the fact that, while some diseases have been described earlier (e.g., mutations in FAS, FASL, and LYST $)(75,184)$ and investigated in more detail, the molecular defects that cause most PIDs with immune dysregulation have only recently been discovered (Figure 1). However, we can confidently estimate that PRF1 deficiency accounts for $30-50 \%$, and UNC13D deficiency for up to $20 \%$ of all FHL cases (34, $105,108,123)$, and mutations in the FAS receptor are the most frequent cause of ALPS [ $\sim 70 \%$ of genetically defined ALPS $(177,178)]$. The incidence of several other PIDs with immune dysregulation remains to be determined when additional patients are discovered. While more than 250 patients with ChediakHigashi syndrome due to LYST deficiency were described 13 years ago (? ), other PIDs we included in this review have been reported only in the last decade and we expect that only a small proportion of these patients have been discovered to date. The establishment of more laboratories capable of molecularly characterizing PIDs with immune dysregulation syndromes throughout the world, including developing countries, will be essential in advancing this new field of immunology. This will allow us to elucidate which defects are indeed rare or common.

Since these syndromes are rare, there is not a high request of specialized assays (e.g., FAS/FASL expression) when compared to other less specialized laboratory tests (e.g., complete blood count and quantitative immunoglobulins determination). Consequently, while the former assays are routinely only performed in PID research centers (often in state universities), which are supported by research grants, less specialized examinations are broadly available in most laboratories. We hope that improving the diagnoses of previously described and newly discovered PIDs with immune dysregulation will encourage governments and other funding sources to promote the establishment of new PID specialized laboratories in underserved geographic areas such as developing countries, where the true incidence of PIDs with immune dysregulation remains to be determined.

Finally, beyond its utility as a screening tool for patients with symptoms of immune dysregulation, flow cytometry has helped to characterize novel immunopathological mechanisms of several recently reported new PIDs. However, new flow cytometric technologies such as time-of-flight mass cytometry (CyTOF) (253) have not yet been applied for characterizing the immunopathology of immune dysregulation syndromes. Equally, flow cytometry is not currently applied in the context of systems immunology studies $(254,255)$ to better understand the immunopathology of diseases of immune dysregulation. For instance, traditional flow cytometry can be used to validate the findings obtained from combinatorial techniques such as CyTOF with high-throughput sequencing of mRNA (RNA-seq) or mass spectrometry, and uncovering systemic immunology defects $(256,257)$. Systems immunology will provide a more comprehensive understanding of the role of specific molecules across immune cells, potentially revealing novel therapeutic targets for patients with diseases of immune dysregulation.

\section{AUTHOR CONTRIBUTIONS}

OC-M: acquisition of data, wrote the manuscript, edited the manuscript, and proof reading. LS, NE, RR, and GS: wrote the manuscript. EO: figure configuration and wrote the manuscript. BA-R: wrote the manuscript, proof reading, and edited the manuscript. $\mathrm{HO}$ and $\mathrm{AC}-\mathrm{N}$ : proof reading, wrote, and edited the manuscript.

\section{ACKNOWLEDGMENTS}

HO is supported by a grant of the Jeffrey Modell Foundation. 


\section{REFERENCES}

1. Matzinger P. The danger model: a renewed sense of self. Science. (2002) 296:301-5. doi: 10.1126/science.1071059

2. Cabral-Marques O, Marques A, Giil LM, De Vito R, Rademacher J, Günther J, et al. GPCR-specific autoantibody signatures are associated with physiological and pathological immune homeostasis. Nat Commun. (2018) 9:5224. doi: 10.1038/s41467-018-07598-9

3. Kotas MEE, Medzhitov R. Homeostasis, inflammation, and disease susceptibility. Cell. (2015) 160:816-27. doi: 10.1016/j.cell.2015.02.010

4. Immunity in the tissues. Nat Immunol. (2013) 14:977. doi: 10.1038/ni.2722

5. Qu F, Guilak F, Mauck RL. Cell migration: implications for repair and regeneration in joint disease. Nat Rev Rheumatol. (2019) 15:167-79. doi: 10.1038/s41584-018-0151-0

6. Bednarski JJ, Sleckman BP. At the intersection of DNA damage and immune responses. Nat Rev Immunol. (2019) 19:231-42. doi: 10.1038/s41577-019-0135-6

7. Schmidt RE, Grimbacher B, Witte T. Autoimmunity and primary immunodeficiency: two sides of the same coin? Nat Rev Rheumatol. (2018) 14:7-18. doi: 10.1038/nrrheum.2017.198

8. Cabral-Marques O, Riemekasten G. Functional autoantibodies targeting G protein-coupled receptors in rheumatic diseases. Nat Rev Rheumatol. (2017) 13:648-56. doi: 10.1038/nrrheum.2017.134

9. Cabral-Marques O, Carvalho-Marques AH, Schimke LF, Heidecke H, Riemekasten G. Loss of balance in normal GPCR-mediated cell trafficking. Front Biosci. (2019) 24:18-34. doi: 10.2741/4707

10. Sánchez-Ramón S, Bermúdez A, González-Granado LI, Rodríguez-Gallego C, Sastre A, Soler-Palacín P, et al. Primary and Secondary Immunodeficiency Diseases in Oncohaematology: Warning Signs, Diagnosis, and Management. Front Immunol. (2019) 10:586.

11. Israel L, Wang Y, Bulek K, Della Mina E, Zhang Z, Pedergnana V, et al. Human adaptive immunity rescues an inborn error of innate immunity. Cell. (2017) 168:789-800.e10. doi: 10.1016/j.cell.2017.01.039

12. Meyts I, Bosch B, Bolze A, Boisson B, Itan Y, Belkadi A, et al. Exome and genome sequencing for inborn errors of immunity. J Allergy Clin Immunol. (2016) 138:957-69. doi: 10.1016/j.jaci.2016.08.003

13. Casanova J-L, Abel L. Genetic dissection of immunity to mycobacteria: the human model. Annu Rev Immunol. (2002) 20:581-620. doi: 10.1146/annurev.immunol.20.081501.125851

14. Casanova J-L. Human genetic basis of interindividual variability in the course of infection. Proc Natl Acad Sci USA. (2015) 112:201521644. doi: 10.1073/pnas.1521644112

15. Casanova J-L, Abel L. Inborn errors of immunity to infection: the rule rather than the exception. J Exp Med. (2005) 202:197-201. doi: 10.1084 /jem.20050854

16. Casanova J-L. Severe infectious diseases of childhood as monogenic inborn errors of immunity. Proc Natl Acad Sci USA. (2015) 112:201521651. doi: $10.1073 /$ pnas. 1521651112

17. Casanova J-L, Abel L. Human genetics of infectious diseases: a unified theory. EMBO J. (2007) 26:915-22. doi: 10.1038/sj.emboj.7601558

18. Bruton OC. Agammaglobulinemia. Pediatrics. (1952) 9:722-8.

19. Notarangelo L, Casanova JL, Fischer A, Puck J, Rosen F, Seger R, Geha R. Primary immunodeficiency diseases: an update. J Allergy Clin Immunol. (2004) 114:677-87. doi: 10.1016/j.jaci.2004.06.044

20. Picard C, Al-Herz W, Bousfiha A, Casanova J-LL, Chatila T, Conley ME, et al. Primary immunodeficiency diseases: an update on the classification from the international union of immunological societies expert committee for primary immunodeficiency 2015. J Clin Immunol. (2015) 35:696-726. doi: 10.1007/s10875-015-0201-1

21. Chinen J, Notarangelo LD, Shearer WT, Turvey SE, Durandy A, Fischer A, et al. Advances in basic and clinical immunology in 2014. J Allergy Clin Immunol. (2015) 135:1132-41. doi: 10.1016/j.jaci.2015. 02.037

22. Greil J, Rausch T, Giese T, Bandapalli OR, Daniel V, Bekeredjian-Ding I, et al. Whole-exome sequencing links caspase recruitment domain 11 (CARD11) inactivation to severe combined immunodeficiency. J Allergy Clin Immunol. (2013) 131:1376-83.e3. doi: 10.1016/j.jaci.2013.02.012
23. Itan Y, Casanova J-L. Novel primary immunodeficiency candidate genes predicted by the human gene connectome. Front Immunol. (2015) 6:142. doi: 10.3389/fimmu.2015.00142

24. Bousfiha A, Jeddane L, Picard C, Ailal F, Bobby Gaspar H, Al-Herz W, et al. The 2017 IUIS phenotypic classification for primary immunodeficiencies. J Clin Immunol. (2018) 38:129-43. doi: 10.1007/s10875-0170465-8

25. Parvaneh N, Casanova J-L, Notarangelo LD, Conley ME. Primary immunodeficiencies: a rapidly evolving story. J Allergy Clin Immunol. (2013) 131:314-23. doi: 10.1016/j.jaci.2012.11.051

26. Tangye SG. Genetic cause of immune dysregulation one gene or two? J Clin Invest. (2016) 126:4065-7. doi: 10.1172/JCI90831

27. Alcaïs A, Quintana-Murci L, Thaler DS, Schurr E, Abel L, Casanova J-L. Life-threatening infectious diseases of childhood: single-gene inborn errors of immunity? Ann NY Acad Sci. (2010) 1214:18-33. doi: $10.1111 / \mathrm{j} .1749-6632.2010 .05834 . \mathrm{x}$

28. Meyts I, Casanova J-L. A human inborn error connects the $\alpha$ 's. Nat Immunol. (2016) 17:472-4. doi: 10.1038/ni.3420

29. Torgerson TR. Genetic disorders of immune tolerance: the flip side of immune deficiency where autoimmunity trumps infection. Blood. (2017) 130.

30. Free Online Timeline Maker. Available online at: https://time.graphics/ (accessed August 13, 2019).

31. van der Burg M, Kalina T, Perez-Andres M, Vlkova M, Lopez-Granados E, Blanco E, et al. The EuroFlow PID orientation tube for flow cytometric diagnostic screening of primary immunodeficiencies of the lymphoid system. Front Immunol. (2019) 10:246. doi: 10.3389/fimmu.2019.00246

32. Oliveira JB, Notarangelo LD, Fleisher TA. Applications of flow cytometry for the study of primary immune deficiencies. Curr Opin Allergy Clin Immunol. (2008) 8:499-509. doi: 10.1097/ACI.0b013e328312c790

33. Abraham RS, Aubert G. Flow cytometry, a versatile tool for diagnosis and monitoring of primary immunodeficiencies. Clin Vaccine Immunol. (2016) 23:254-71. doi: 10.1128/CVI.00001-16

34. Kanegane H, Hoshino A, Okano T, Yasumi T, Wada T, Takada H, Okada S, et al. Flow cytometry-based diagnosis of primary immunodeficiency diseases. Allergol Int. (2018) 67:43-54. doi: 10.1016/j.alit.2017.06.003

35. Takashima T, Okamura M, Yeh T, Okano T, Yamashita M, Tanaka K, et al. Multicolor flow cytometry for the diagnosis of primary immunodeficiency diseases. J Clin Immunol. (2017) 37:486-95. doi: 10.1007/s10875-017-0405-7

36. Chiang SCC, Bleesing JJ, Marsh RA. Current flow cytometric assays for the screening and diagnosis of primary HLH. Front Immunol. (2019) 10:1740. doi: 10.3389/fimmu.2019.01740

37. Massaad MJ, Zhou J, Tsuchimoto D, Chou J, Jabara H, Janssen E, et al. Deficiency of base excision repair enzyme NEIL3 drives increased predisposition to autoimmunity. J Clin Invest. (2016) 126:4219-36. doi: 10.1172/JCI85647

38. Janssen E, Morbach H, Ullas S, Bannock JM, Massad C, Menard L, et al. Dedicator of cytokinesis 8-deficient patients have a breakdown in peripheral B-cell tolerance and defective regulatory T cells. J Allergy Clin Immunol. (2014) 134:1365-74. doi: 10.1016/j.jaci.2014.07.042

39. Issac JM, Mohamed YA, Bashir GH, Al-Sbiei A, Conca W, Khan $\mathrm{TA}$, et al. Induction of hypergammaglobulinemia and autoantibodies by Salmonella infection in MyD88-deficient mice. Front Immunol. (2018) 9:1384. doi: 10.3389/fimmu.2018.01384

40. Romberg N, Al Moussawi K, Nelson-Williams C, Stiegler AL, Loring E, Choi M, et al. Mutation of NLRC4 causes a syndrome of enterocolitis and autoinflammation. Nat Genet. (2014) 46:1135-9. doi: 10.1038/ng.3066

41. Sauer AV, Morbach H, Brigida I, Ng Y-S, Aiuti A, Meffre E. Defective B cell tolerance in adenosine deaminase deficiency is corrected by gene therapy. $J$ Clin Invest. (2012) 122:2141-52. doi: 10.1172/JCI61788

42. Ombrello MJ, Remmers EF, Sun G, Freeman AF, Datta S, Torabi-Parizi P, et al. Cold urticaria, immunodeficiency, and autoimmunity related to PLCG2 deletions. N Engl J Med. (2012) 366:330-8. doi: 10.1056/NEJMoa1102140

43. Isnardi I, Ng Y-S, Srdanovic I, Motaghedi R, Rudchenko S, von Bernuth H, et al. IRAK-4- and MyD88-dependent pathways are essential for the removal of developing autoreactive B cells in humans. Immunity. (2008) 29:746-57. doi: 10.1016/j.immuni.2008.09.015 
44. Du Y, Yan L, Wang J, Zhan W, Song K, Han X, et al. $\beta 1$-Adrenoceptor autoantibodies from DCM patients enhance the proliferation of $\mathrm{T}$ lymphocytes through the $\beta 1-\mathrm{AR} / \mathrm{cAMP} / \mathrm{PKA}$ and $\mathrm{p} 38$ MAPK pathways. PLoS ONE. (2012) 7:e52911. doi: 10.1371/journal.pone.0052911

45. Cooper MD, Faulk WP, Fudenberg HH, Good RA, Hitzig W, Kunkel H, et al. Classification of primary immunodeficiencies. N Engl J Med. (1973) 288:966-7. doi: 10.1056/NEJM197305032881814

46. Primary Immunodeficiency Diseases Report of an IUIS Scientific Committee. Clin Exp Immunol. (1999) 118:1-28.

47. Montojo J, Zuberi K, Rodriguez H, Kazi F, Wright G, Donaldson SL, et al. GeneMANIA Cytoscape plugin: fast gene function predictions on the desktop. Bioinformatics. (2010) 26:2927-8. doi: 10.1093/bioinformatics/btq562

48. Motifolio: Scientific illustration Toolkits for Presentations and Publications. Available online at: www.motifolio.com

49. Bryceson YT, Pende D, Maul-Pavicic A, Gilmour KC, Ufheil H, Vraetz $\mathrm{T}$, et al. A prospective evaluation of degranulation assays in the rapid diagnosis of familial hemophagocytic syndromes. Blood. (2012) 119:2754-63. doi: 10.1182/blood-2011-08-374199

50. Nagle DL, Karim MA, Woolf EA, Holmgren L, Bork P, Misumi DJ, et al. Identification and mutation analysis of the complete gene for ChediakHigashi syndrome. Nat Genet. (1996) 14:307-11. doi: 10.1038/ng1196-307

51. Barbosa MDFS, Nguyen QA, Tchernev VT, Ashley JA, Detter JC, Blaydes SM, et al. Identification of the homologous beige and Chediak-Higashi syndrome genes. Nature. (1996) 382:262-5. doi: 10.1038/382262a0

52. Ménasché G, Pastural E, Feldmann J, Certain S, Ersoy F, Dupuis S, et al. Mutations in RAB27A cause Griscelli syndrome associated with haemophagocytic syndrome. Nat Genet. (2000) 25:173-6. doi: 10.1038/76024

53. Dell'Angelica EC, Shotelersuk V, Aguilar RC, Gahl WA, Bonifacino JS. Altered trafficking of lysosomal proteins in Hermansky-Pudlak syndrome due to mutations in the beta 3A subunit of the AP-3 adaptor. Mol Cell. (1999) 3:11-21. doi: 10.1016/S1097-2765(00)80170-7

54. Ammann S, Schulz A, Krageloh-Mann I, Dieckmann NMG, Niethammer K, Fuchs S, et al. Mutations in AP3D1 associated with immunodeficiency and seizures define a new type of Hermansky-Pudlak syndrome. Blood. (2016) 127:997-1006. doi: 10.1182/blood-2015-09-671636

55. Stepp SE, Dufourcq-Lagelouse R, Le Deist F, Bhawan S, Certain S, Mathew PA, et al. Perforin gene defects in familial hemophagocytic lymphohistiocytosis. Science. (1999) 286:1957-9. doi: $10.1126 /$ science.286.5446.1957

56. Allen M, De Fusco C, Legrand F, Clementi R, Conter V, Danesino C, et al. Familial hemophagocytic lymphohistiocytosis: how late can the onset be? Haematologica. (2001) 86:499-503.

57. zur Stadt U, Schmidt S, Kasper B, Beutel K, Diler AS, Henter J-I, et al. Linkage of familial hemophagocytic lymphohistiocytosis (FHL) type-4 to chromosome 6q24 and identification of mutations in syntaxin 11. Hum Mol Genet. (2005) 14:827-34. doi: 10.1093/hmg/ddi076

58. Côte M, Ménager MM, Burgess A, Mahlaoui N, Picard C, Schaffner C, et al. Munc18-2 deficiency causes familial hemophagocytic lymphohistiocytosis type 5 and impairs cytotoxic granule exocytosis in patient NK cells. J Clin Invest. (2009) 119:3765-73. doi: 10.1172/JCI40732

59. Mao H, Yang W, Latour S, Yang J, Winter S, Zheng J, et al. RASGRP1 mutation in autoimmune lymphoproliferative syndromelike disease. J Allergy Clin Immunol. (2018) 142:595-604.e16. doi: 10.1016/j.jaci.2017.10.026

60. Salzer E, Cagdas D, Hons M, Mace EM, Garncarz W, Petronczki ÖY, et al. RASGRP1 deficiency causes immunodeficiency with impaired cytoskeletal dynamics. Nat Immunol. (2016) 17:1352-60. doi: 10.1038/ni.3575

61. Winter S, Martin E, Boutboul D, Lenoir C, Boudjemaa S, Petit A, et al. Loss of RASGRP1 in humans impairs T-cell expansion leading to Epstein-Barr virus susceptibility. EMBO Mol Med. (2018) 10:188-99. doi: 10.15252/emmm.201708292

62. Platt CD, Fried AJ, Hoyos-Bachiloglu R, Usmani GN, Schmidt B, et al. Combined immunodeficiency with EBV positive B cell lymphoma and epidermodysplasia verruciformis due to a novel homozygous mutation in RASGRP1. Clin Immunol. (2017) 183:142-4. doi: 10.1016/j.clim.2017.08.007

63. Somekh I, Marquardt B, Liu Y, Rohlfs M, Hollizeck S, Karakukcu M, et al. Novel mutations in RASGRP1 are associated with immunodeficiency, immune dysregulation, and EBV-induced lymphoma. J Clin Immunol. (2018) 38:699-710. doi: 10.1007/s10875-018-0533-8

64. Izawa K, Martin E, Soudais C, Bruneau J, Boutboul D, Rodriguez R, et al. Inherited CD70 deficiency in humans reveals a critical role for the CD70CD27 pathway in immunity to Epstein-Barr virus infection. J Exp Med. (2017) 214:73-89. doi: 10.1084/jem.20160784

65. Martin E, Palmic N, Sanquer S, Lenoir C, Hauck F, Mongellaz C, et al. CTP synthase 1 deficiency in humans reveals its central role in lymphocyte proliferation. Nature. (2014) 510:288-92. doi: 10.1038/nature 13386

66. Wang Y, Ma CS, Ling Y, Bousfiha A, Camcioglu Y, Jacquot S, et al. Dual T celland B cell-intrinsic deficiency in humans with biallelic RLTPR mutations. $J$ Exp Med. (2016) 213:2413-35. doi: 10.1084/jem.20160576

67. Linka RM, Risse SL, Bienemann K, Werner M, Linka Y, Krux F, et al. Lossof-function mutations within the IL-2 inducible kinase ITK in patients with EBV-associated lymphoproliferative diseases. Leukemia. (2012) 26:963-71. doi: 10.1038/leu.2011.371

68. Li F-Y, Chaigne-Delalande B, Kanellopoulou C, Davis JC, Matthews HF, Douek DC, et al. Second messenger role for $\mathrm{Mg}^{+}$revealed by human T-cell immunodeficiency. Nature. (2011) 475:471-6. doi: 10.1038/nature 10246

69. Salzer E, Santos-Valente E, Klaver S, Ban SA, Emminger W, Prengemann NK, et al. B-cell deficiency and severe autoimmunity caused by deficiency of protein kinase C $\delta$. Blood. (2013) 121:3112-6. doi: 10.1182/blood-2012-10-460741

70. Kuehn HS, Niemela JE, Rangel-Santos A, Zhang M, Pittaluga S, Stoddard $\mathrm{JL}$, et al. Loss-of-function of the protein kinase $\mathrm{C} \delta(\mathrm{PKC} \delta)$ causes a Bcell lymphoproliferative syndrome in humans. Blood. (2013) 121:3117-25. doi: 10.1182/blood-2012-12-469544

71. Belot A, Kasher PR, Trotter EW, Foray A-P, Debaud A-L, Rice GI, et al. Protein kinase $c \delta$ deficiency causes mendelian systemic lupus erythematosus with B cell-defective apoptosis and hyperproliferation. Arthritis Rheum. (2013) 65:2161-71. doi: 10.1002/art.38008

72. Coffey AJ, Brooksbank RA, Brandau O, Oohashi T, Howell GR, Bye JM, et al. Host response to EBV infection in X-linked lymphoproliferative disease results from mutations in an SH2-domain encoding gene. Nat Genet. (1998) 20:129-35. doi: 10.1038/2424

73. Rigaud S, Fondanèche M-C, Lambert N, Pasquier B, Mateo V, Soulas P, et al. XIAP deficiency in humans causes an X-linked lymphoproliferative syndrome. Nature. (2006) 444:110-4. doi: 10.1038/nature05257

74. van Montfrans JM, Hoepelman AIM, Otto S, van Gijn M, van de Corput $\mathrm{L}$, de Weger RA, et al. CD27 deficiency is associated with combined immunodeficiency and persistent symptomatic EBV viremia. J Allergy Clin Immunol. (2012) 129:787-793.e6. doi: 10.1016/j.jaci.2011.11.013

75. Rieux-Laucat F, Le Deist F, Hivroz C, Roberts I, Debatin K, Fischer A, et al. Mutations in Fas associated with human lymphoproliferative syndrome and autoimmunity. Science. (1995) 268:1347-9. doi: 10.1126/science.7539157

76. Wu J, Wilson J, He J, Xiang L, Schur PH, Mountz JD. Fas ligand mutation in a patient with systemic lupus erythematosus and lymphoproliferative disease. J Clin Invest. (1996) 98:1107-13. doi: 10.1172/JCI118892

77. Chun HJ, Zheng L, Ahmad M, Wang J, Speirs CK, Siegel RM, et al. Pleiotropic defects in lymphocyte activation caused by caspase- 8 mutations lead to human immunodeficiency. Nature. (2002) 419:395-9. doi: 10.1038/nature01063

78. Wang J, Zheng L, Lobito A, Chan FK-M, Dale J, Sneller M, et al. Inherited human caspase 10 mutations underlie defective lymphocyte and dendritic cell apoptosis in autoimmune lymphoproliferative syndrome type II. Cell. (1999) 98:47-58. doi: 10.1016/S0092-8674(00)80605-4

79. Bolze A, Byun M, McDonald D, Morgan NV, Abhyankar A, Premkumar L, et al. Whole-exome-sequencing-based discovery of human FADD deficiency. Am J Hum Genet. (2010) 87:873-81. doi: 10.1016/j.ajhg.2010.10.028

80. Lopez-Herrera G, Tampella G, Pan-Hammarström Q, Herholz P, TrujilloVargas CM, Phadwal K, et al. Deleterious mutations in LRBA are associated with a syndrome of immune deficiency and autoimmunity. Am J Hum Genet. (2012) 90:986-1001. doi: 10.1016/j.ajhg.2012.04.015

81. Flanagan SE, Haapaniemi E, Russell MA, Caswell R, Allen HL, De Franco E, et al. Activating germline mutations in STAT3 cause early-onset multi-organ autoimmune disease. Nat Genet. (2014) 46:812-4. doi: 10.1038/ng.3040 
82. Bennett CL, Christie J, Ramsdell F, Brunkow ME, Ferguson PJ, Whitesell $\mathrm{L}$, et al. The immune dysregulation, polyendocrinopathy, enteropathy, Xlinked syndrome (IPEX) is caused by mutations of FOXP3. Nat Genet. (2001) 27:20-1. doi: 10.1038/83713

83. Sharfe N, Dadi HK, Shahar M, Roifman CM. Human immune disorder arising from mutation of the $\alpha$ chain of the interleukin-2 receptor. Proc Natl Acad Sci USA. (1997) 94:3168-71. doi: 10.1073/pnas.94.7.3168

84. Kuehn HS, Ouyang W, Lo B, Deenick EK, Niemela JE, Avery DT, et al. Immune dysregulation in human subjects with heterozygous germline mutations in CTLA4. Science. (2014) 345:1623-7. doi: 10.1126/science.1255904

85. Afzali B, Grönholm J, Vandrovcova J, O’Brien C, Sun H-W, Vanderleyden $\mathrm{I}$, et al. BACH2 immunodeficiency illustrates an association between super-enhancers and haploinsufficiency. Nat Immunol. (2017) 18:813-23. doi: $10.1038 /$ ni. 3753

86. Aaltonen J, Björses P, Perheentupa J, Horelli-Kuitunen N, Palotie A, Peltonen $\mathrm{L}$, et al. An autoimmune disease, APECED, caused by mutations in a novel gene featuring two PHD-type zinc-finger domains. Nat Genet. (1997) 17:399-403. doi: 10.1038/ng1297-399

87. Stepensky P, Rensing-Ehl A, Gather R, Revel-Vilk S, Fischer U, Nabhani $S$, et al. Early-onset Evans syndrome, immunodeficiency, and premature immunosenescence associated with tripeptidyl-peptidase II deficiency. Blood. (2015) 125:753-61. doi: 10.1182/blood-2014-08-593202

88. Del Bel KL, Ragotte RJ, Saferali A, Lee S, Vercauteren SM, Mostafavi SA, Schreiber RA, et al. JAK1 gain-of-function causes an autosomal dominant immune dysregulatory and hypereosinophilic syndrome. J Allergy Clin Immunol. (2017) 139:2016-20.e5. doi: 10.1016/j.jaci.2016.12.957

89. Glocker E-O, Kotlarz D, Klein C, Shah N, Grimbacher B. IL-10 and IL10 receptor defects in humans. Ann NY Acad Sci. (2011) 1246:102-7. doi: 10.1111/j.1749-6632.2011.06339.x

90. Glocker E-O, Kotlarz D, Boztug K, Gertz EM, Schäffer AA, Noyan F, et al. Inflammatory bowel disease and mutations affecting the interleukin-10 receptor. N Engl J Med. (2009) 361:2033-45. doi: 10.1056/NEJMoa0907206

91. Collis SJ, Ciccia A, Deans AJ, Horejší Z, Martin JS, Maslen SL, et al. FANCM and FAAP24 function in ATR-mediated checkpoint signaling independently of the fanconi anemia core complex. Mol Cell. (2008) 32:31324. doi: 10.1016/j.molcel.2008.10.014

92. Lohr NJ, Molleston JP, Strauss KA, Torres-Martinez W, Sherman EA, Squires $\mathrm{RH}$, et al. Human ITCH E3 ubiquitin ligase deficiency causes syndromic multisystem autoimmune disease. Am J Hum Genet. (2010) 86:447-53. doi: 10.1016/j.ajhg.2010.01.028

93. Ciccia A, Ling C, Coulthard R, Yan Z, Xue Y, Meetei AR, et al. Identification of FAAP24, a fanconi anemia core complex protein that interacts with FANCM. Mol Cell. (2007) 25:331-43. doi: 10.1016/j.molcel.2007.01.003

94. Mueller DL. E3 ubiquitin ligases as T cell anergy factors. Nat Immunol. (2004) 5:883-90. doi: 10.1038/ni1106

95. Tanoue A, Endo F, Kitano A, Matsuda I. A single nucleotide change in the prolidase gene in fibroblasts from two patients with polypeptide positive prolidase deficiency. Expression of the mutant enzyme in NIH 3T3 cells. $J$ Clin Invest. (1990) 86:351-5. doi: 10.1172/JCI114708

96. Shrinath M, Walter JH, Haeney M, Couriel JM, Lewis MA, Herrick AL. Prolidase deficiency and systemic lupus erythematosus. Arch Dis Child. (1997) 76:441-4. doi: 10.1136/adc.76.5.441

97. Chan AY, Punwani D, Kadlecek TA, Cowan MJ, Olson JL, Mathes EF, et al. A novel human autoimmune syndrome caused by combined hypomorphic and activating mutations in ZAP-70. J Exp Med. (2016) 213:155-65. doi: 10.1084/jem.20150888

98. Boland BS, Widjaja CE, Banno A, Zhang B, Kim SH, Stoven S, et al. Immunodeficiency and autoimmune enterocolopathy linked to NFAT5 haploinsufficiency. (2015) 194:2551-60. doi: 10.4049/jimmunol.1401463

99. Cady FM, Morice WG. Flow cytometric assessment of T-cell chronic lymphoproliferative disorders. Clin Lab Med. (2007) 27:513-32. doi: 10.1016/j.cll.2007.05.004

100. Maecker HT, Trotter J. Flow cytometry controls, instrument setup, and the determination of positivity. Cytometry A. (2006) 69:1037-42. doi: 10.1002/cyto.a.20333

101. Cossarizza A, Chang H-D, Radbruch A, Akdis M, Andrä I, Annunziato F, et al. Guidelines for the use of flow cytometry and cell sorting in immunological studies. Eur J Immunol. (2017) 47:1584-797. doi: 10.1002/eji.201646632

102. Richardson AM, Moyer AM, Hasadsri L, Abraham RS. Diagnostic tools for inborn errors of human immunity (primary immunodeficiencies and immune dysregulatory diseases). Curr Allergy Asthma Rep. (2018) 18:19. doi: 10.1007/s11882-018-0770-1

103. Kalina T, Lundsten K, Engel P. Relevance of antibody validation for flow cytometry. Cytom Part A. (2019). doi: 10.1002/cyto.a.23895. [Epub ahead of print].

104. Kalina T. Reproducibility of flow cytometry through standardization: opportunities and challenges. Cytometry A. (2019). doi: 10.1002/cyto.a.23901. [Epub ahead of print].

105. Murata Y, Yasumi T, Shirakawa R, Izawa K, Sakai H, Abe J, et al. Rapid diagnosis of FHL3 by flow cytometric detection of intraplatelet Munc13-4 protein. Blood. (2011) 118:1225-30. doi: 10.1182/blood-2011-01-329540

106. Kogawa K, Lee SM, Villanueva J, Marmer D, Sumegi J, Filipovich AH. Perforin expression in cytotoxic lymphocytes from patients with hemophagocytic lymphohistiocytosis and their family members. Blood. (2002) 99:61-6. doi: 10.1182/blood.V99.1.61

107. Sieni E, Cetica V, Hackmann Y, Coniglio ML, Da Ros M, Ciambotti B, et al. Familial hemophagocytic lymphohistiocytosis: when rare diseases shed light on immune system functioning. Front Immunol. (2014) 5:167. doi: 10.3389/fimmu.2014.00167

108. Voskoboinik I, Smyth MJ, Trapani JA. Perforin-mediated target-cell death and immune homeostasis. Nat Rev Immunol. (2006) 6:940-52. doi: $10.1038 /$ nri1983

109. Lozano ML, Rivera J, Sánchez-Guiu I, Vicente V. Towards the targeted management of Chediak-Higashi syndrome. Orphanet J Rare Dis. (2014) 9:132. doi: 10.1186/s13023-014-0132-6

110. Griscelli C, Durandy A, Guy-Grand D, Daguillard F, Herzog C, Prunieras M. A syndrome associating partial albinism and immunodeficiency. Am J Med. (1978) 65:691-702. doi: 10.1016/0002-9343(78)90858-6

111. Jordan $\mathrm{MB}$, Filipovich AH. Hematopoietic cell transplantation for hemophagocytic lymphohistiocytosis: a journey of a thousand miles begins with a single (big) step. Bone Marrow Transplant. (2008) 42:433-7. doi: $10.1038 /$ bmt.2008.232

112. Cairo MS, Vandeven C, Toy C, Tischler D, Sender L. Fluorescent cytometric analysis of polymorphonuclear leukocytes in ChediakHigashi Syndrome: diminished C3bi receptor expression (OKM1) with normal granular cell density. Pediatr Res. (1988) 24:673-6. doi: 10.1203/00006450-198812000-00004

113. Cetica V, Hackmann Y, Grieve S, Sieni E, Ciambotti B, Coniglio ML, et al. Patients with Griscelli syndrome and normal pigmentation identify RAB27A mutations that selectively disrupt MUNC13-4 binding. J Allergy Clin Immunol. (2015) 135:1310-8.e1. doi: 10.1016/j.jaci.2014.08.039

114. Marks MS, Seabra MC. The melanosome: membrane dynamics in black and white. Nat Rev Mol Cell Biol. (2001) 2:738-48. doi: 10.1038/35096009

115. Stinchcombe J, Bossi G, Griffiths GM. Linking albinism and immunity: the secrets of secretory lysosomes. Science. (2004) 305:55-9. doi: 10.1126/science.1095291

116. Kaplan J, De Domenico I, Ward DM. Chediak-Higashi syndrome. Curr Opin Hematol. (2008) 15:22-9. doi: 10.1097/MOH.0b013e3282f2bcce

117. Bryceson YT, March ME, Barber DF, Ljunggren H-G, Long EO. Cytolytic granule polarization and degranulation controlled by different receptors in resting NK cells. J Exp Med. (2005) 202:1001-12. doi: 10.1084/jem.20051143

118. Peters PJ, Borst J, Oorschot V, Fukuda M, Krähenbühl O, Tschopp $\mathrm{J}$, et al. Cytotoxic $\mathrm{T}$ lymphocyte granules are secretory lysosomes, containing both perforin and granzymes. J Exp Med. (1991) 173:1099-109. doi: 10.1084/jem.173.5.1099

119. Betts MR, Brenchley JM, Price DA, De Rosa SC, Douek DC, Roederer M, et al. Sensitive and viable identification of antigen-specific CD8+ T cells by a flow cytometric assay for degranulation. J Immunol Methods. (2003) 281:65-78. doi: 10.1016/S0022-1759(03)00265-5

120. Alter G, Malenfant JM, Altfeld M. CD107a as a functional marker for the identification of natural killer cell activity. J Immunol Methods. (2004) 294:15-22. doi: 10.1016/j.jim.2004.08.008

121. Jessen B, Bode SFN, Ammann S, Chakravorty S, Davies G, Diestelhorst J, et al. The risk of hemophagocytic lymphohistiocytosis 
in Hermansky-Pudlak syndrome type 2. Blood. (2013) 121:2943-51. doi: 10.1182/blood-2012-10-463166

122. Betts MR, Koup RA. Detection of T-cell degranulation: CD107a and b. Methods Cell Biol. (2004) 75:497-512. doi: 10.1016/S0091-679X(04)75020-7

123. Shibata H, Yasumi T, Shimodera S, Hiejima E, Izawa K, Kawai T, et al. Human CTL-based functional analysis shows the reliability of a munc134 protein expression assay for FHL3 diagnosis. Blood. (2018) 131:2016-25. doi: 10.1182/blood-2017-10-812503

124. Marcenaro S, Gallo F, Martini S, Santoro A, Griffiths GM, Aricó M, et al. Analysis of natural killer-cell function in familial hemophagocytic lymphohistiocytosis (FHL): defective CD107a surface expression heralds Munc13-4 defect and discriminates between genetic subtypes of the disease. Blood. (2006) 108:2316-23. doi: 10.1182/blood-2006-04-015693

125. Feldmann J, Callebaut I, Raposo G, Certain S, Bacq D, Dumont C, et al. Munc13-4 is essential for cytolytic granules fusion and is mutated in a form of familial hemophagocytic lymphohistiocytosis (FHL3). Cell. (2003) 115:461-73. doi: 10.1016/S0092-8674(03)00855-9

126. Daschkey S, Bienemann K, Schuster V, Kreth HW, Linka RM, Hönscheid A, et al. Fatal lymphoproliferative disease in two siblings lacking functional FAAP24. J Clin Immunol. (2016) 36:684-92. doi: 10.1007/s10875-016-0317-y

127. Ovadia A, Dalal I. Epstein-Barr virus infection in primary immunodeficiency. LymphoSign J. (2018) 5:65-85. doi: 10.14785/lymphosign-2018-0011

128. Worth AJJ, Houldcroft CJ, Booth C. Severe Epstein-Barr virus infection in primary immunodeficiency and the normal host. Br J Haematol. (2016) 175:559-76. doi: 10.1111/bjh.14339

129. Tangye SG, Palendira U, Edwards ESJ. Human immunity against EBV-lessons from the clinic. J Exp Med. (2017) 214:269-83. doi: $10.1084 /$ jem. 20161846

130. Taylor GS, Long HM, Brooks JM, Rickinson AB, Hislop AD. The immunology of Epstein-Barr virus-induced disease. Annu Rev Immunol. (2015) 33:787-821. doi: 10.1146/annurev-immunol-032414-112326

131. Trück J, Kelly DF, Taylor JM, Kienzler AK, Lester T, Seller A, et al. Variable phenotype and discrete alterations of immune phenotypes in CTP synthase 1 deficiency: report of 2 siblings. J Allergy Clin Immunol. (2016) 138:1722-5.e6. doi: 10.1016/j.jaci.2016.04.059

132. Serwas NK, Cagdas D, Ban SA, Bienemann K, Salzer E, Tezcan I, et al. Identification of ITK deficiency as a novel genetic cause of idiopathic CD4+ T-cell lymphopenia. Blood. (2014) 124:655-7. doi: 10.1182/blood-2014-03-564930

133. Nichols KE, Harkin DP, Levitz S, Krainer M, Kolquist KA, Genovese C, et al. Inactivating mutations in an SH2 domain-encoding gene in X-linked lymphoproliferative syndrome. Proc Natl Acad Sci USA. (1998) 95:13765-70. doi: 10.1073/pnas.95.23.13765

134. Alkhairy OK, Perez-Becker R, Driessen GJ, Abolhassani H, van Montfrans J, Borte S, et al. Novel mutations in TNFRSF7/CD27: clinical, immunologic, and genetic characterization of human CD27 deficiency. J Allergy Clin Immunol. (2015) 136:703-712.e10. doi: 10.1016/j.jaci.2015.02.022

135. França TT, Barreiros LA, al-Ramadi BK, Ochs HD, Cabral-Marques O, Condino-Neto A. CD40 ligand deficiency: treatment strategies and novel therapeutic perspectives. Expert Rev Clin Immunol. (2019) 15:529-40. doi: 10.1080/1744666X.2019.1573674

136. Cabral-Marques O, França TT, Al-Sbiei A, Schimke LF, Khan TA, Feriotti C, et al. CD40 ligand deficiency causes functional defects of peripheral neutrophils that are improved by exogenous IFN- $\gamma$. J Allergy Clin Immunol. (2018) 142:1571-88. doi: 10.1016/j.jaci.2018.02.026

137. Fischer A. Recent advances in understanding the pathophysiology of primary T cell immunodeficiencies. Trends Mol Med. (2015) 21:408-16. doi: 10.1016/j.molmed.2015.04.002

138. Grommé M, Uytdehaag FG, Janssen H, Calafat J, van Binnendijk RS, Kenter $\mathrm{MJ}$, et al. Recycling MHC class I molecules and endosomal peptide loading. Proc Natl Acad Sci USA. (1999) 96:10326-31. doi: 10.1073/pnas.96.18.10326

139. Kobata T, Jacquot S, Kozlowski S, Agematsu K, Schlossman SF, Morimoto C. CD27-CD70 interactions regulate B-cell activation by T cells. Proc Natl Acad Sci USA. (1995) 92:11249-53. doi: 10.1073/pnas.92.24.11249

140. Keller AM, Groothuis TA, Veraar EAM, Marsman M, de Buy Wenniger $\mathrm{LM}$, Janssen $\mathrm{H}$, et al. Costimulatory ligand CD70 is delivered to the immunological synapse by shared intracellular trafficking with MHC class II molecules. Proc Natl Acad Sci USA. (2007) 104:5989-94. doi: 10.1073/pnas.0700946104

141. Munitic I, Kuka M, Allam A, Scoville JP, Ashwell JD. CD70 deficiency impairs effector CD8 T cell generation and viral clearance but is dispensable for the recall response to lymphocytic choriomeningitis virus. J Immunol. (2013) 190:1169-79. doi: 10.4049/jimmunol.1202353

142. Abolhassani H, Edwards ESJ, Ikinciogullari A, Jing H, Borte S, Buggert M, et al. Combined immunodeficiency and Epstein-Barr virus-induced B cell malignancy in humans with inherited CD70 deficiency. J Exp Med. (2017) 214:91-106. doi: 10.1084/jem.20160849

143. Salzer E, Daschkey S, Choo S, Gombert M, Santos-Valente E, Ginzel $S$, et al. Combined immunodeficiency with life-threatening EBVassociated lymphoproliferative disorder in patients lacking functional CD27. Haematologica. (2013) 98:473-8. doi: 10.3324/haematol.2012.068791

144. Seyama K, Nonoyama S, Gangsaas I, Hollenbaugh D, Pabst HF, Aruffo A, et al. Mutations of the CD40 ligand gene and its effect on CD40 ligand expression in patients with X-linked hyper IgM syndrome. Blood. (1998) 92:2421-34. doi: 10.1182/blood.V92.7.2421

145. Cabral-Marques O, Klaver S, Schimke LF, Ascendino EH, Khan TA, Pereira PVS, et al. First report of the hyper-IgM syndrome registry of the latin american society for immunodeficiencies: novel mutations, unique infections, and outcomes. J Clin Immunol. (2014) 34:146-56. doi: 10.1007/s10875-013-9980-4

146. Roncagalli R, Cucchetti M, Jarmuzynski N, Grégoire C, Bergot E, Audebert $\mathrm{S}$, et al. The scaffolding function of the RLTPR protein explains its essential role for CD28 co-stimulation in mouse and human T cells. J Exp Med. (2016) 213:2437-57. doi: 10.1084/jem.20160579

147. Schober T, Magg T, Laschinger M, Fröhlich T, Rohlfs M, Liu Y, Puchalka J, et al. Rltpr is a central scaffold protein regulating human TCR co-signaling and cytoskeletal dynamics. Blood. (2016) 128:131. doi: 10.1182/blood.V128.22.131.131

148. Alazami AM, Al-Helale M, Alhissi S, Al-Saud B, Alajlan H, Monies D, et al. Novel CARMIL2 mutations in patients with variable clinical dermatitis, infections, and combined immunodeficiency. Front Immunol. (2018) 9:203. doi: 10.3389/fimmu.2018.00203

149. Schimke LF, Rieber N, Rylaarsdam S, Cabral-Marques O, Hubbard N, Puel A, et al. A novel gain-of-function IKBA mutation underlies ectodermal dysplasia with immunodeficiency and polyendocrinopathy. J Clin Immunol. (2013) 33:1088-99. doi: 10.1007/s10875-013-9906-1

150. Khan TA, Schimke LF, Amaral EP, Ishfaq M, Barbosa Bonfim CC, Rahman $\mathrm{H}$, et al. Interferon-gamma reduces the proliferation of $\mathrm{M}$. tuberculosis within macrophages from a patient with a novel hypomorphic NEMO mutation. Pediatr Blood Cancer. (2016) 63:1863-6. doi: 10.1002/pbc. 26098

151. Schober T, Magg T, Laschinger M, Rohlfs M, Linhares ND, Puchalka J, et al. A human immunodeficiency syndrome caused by mutations in CARMIL2. Nat Commun. (2017) 8:14209. doi: 10.1038/ncomms14209

152. van den Berg AA, van Lenthe H, Kipp JB, de Korte D, van Kuilenburg AB, van Gennip AH. Cytidine triphosphate (CTP) synthetase activity during cell cycle progression in normal and malignant T-lymphocytic cells. Eur J Cancer. (1995) 31A:108-12. doi: 10.1016/0959-8049(94)00442-8

153. Proteintech. CTP Synthase Antibody. Available online at: https://www.ptglab. com/Products/CTPS-Antibody-15914-1-AP.htm (accessed June 14, 2019).

154. Atherly LO, Lucas JA, Felices M, Yin CC, Reiner SL, Berg LJ. The Tec family tyrosine kinases Itk and Rlk regulate the development of conventional CD8+ T cells. Immunity. (2006) 25:79-91. doi: 10.1016/j.immuni.2006.05.012

155. Ghosh S, Drexler I, Bhatia S, Adler H, Gennery AR, Borkhardt A. Interleukin-2-inducible T-cell kinase deficiency-new patients, new insight? Front Immunol. (2018) 9:979. doi: 10.3389/fimmu.2018.00979

156. Huck K, Feyen O, Niehues T, Rüschendorf F, Hübner N, Laws H-J, et al. Girls homozygous for an IL-2-inducible T cell kinase mutation that leads to protein deficiency develop fatal EBV-associated lymphoproliferation. J Clin Invest. (2009) 119:1350-8. doi: 10.1172/JCI37901

157. Yang W, Lee JY, Nowotny M. Making and breaking nucleic acids: two$\mathrm{Mg}^{+}$-ion catalysis and substrate specificity. Mol Cell. (2006) 22:5-13. doi: $10.1016 /$ j.molcel.2006.03.013

158. Cowan JA. Structural and catalytic chemistry of magnesium-dependent enzymes. Biometals. (2002) 15:225-35. doi: 10.1023/A:1016022730880 
159. Junge S, Kloeckener-Gruissem B, Zufferey R, Keisker A, Salgo B, Fauchere J$\mathrm{C}$, et al. Correlation between recent thymic emigrants and CD31+ (PECAM1) $\mathrm{CD} 4+\mathrm{T}$ cells in normal individuals during aging and in lymphopenic children. Eur J Immunol. (2007) 37:3270-80. doi: 10.1002/eji.200636976

160. Douek DC, McFarland RD, Keiser PH, Gage EA, Massey JM, Haynes BF, et al. Changes in thymic function with age and during the treatment of HIV infection. Nature. (1998) 396:690-5. doi: 10.1038/25374

161. Kohler S, Wagner U, Pierer M, Kimmig S, Oppmann B, Möwes B, et al. Post-thymic in vivo proliferation of naive $\mathrm{CD} 4+\mathrm{T}$ cells constrains the TCR repertoire in healthy human adults. Eur J Immunol. (2005) 35:1987-94. doi: 10.1002/eji.200526181

162. Chaigne-Delalande B, Li F-Y, O'Connor GM, Lukacs MJ, Jiang P, Zheng $\mathrm{L}$, et al. $\mathrm{Mg}^{+}$regulates cytotoxic functions of $\mathrm{NK}$ and $\mathrm{CD} 8 \mathrm{~T}$ cells in chronic EBV infection through NKG2D. Science. (2013) 341:186-91. doi: $10.1126 /$ science. 1240094

163. Lei L, Muhammad S, Al-Obaidi M, Sebire N, Cheng IL, Eleftheriou D, et al. Successful use of ofatumumab in two cases of early-onset juvenile SLE with thrombocytopenia caused by a mutation in protein kinase C $\delta$. Pediatr Rheumatol. (2018) 16:61. doi: 10.1186/s12969-018-0278-1

164. Altman A, Kong K-F. Protein kinase C enzymes in the hematopoietic and immune systems. Annu Rev Immunol. (2016) 34:511-38. doi: 10.1146/annurev-immunol-041015-055347

165. Spitaler M, Cantrell DA. Protein kinase C and beyond. Nat Immunol. (2004) 5:785-90. doi: 10.1038/ni1097

166. Mecklenbräuker I, Saijo K, Zheng N-Y, Leitges M, Tarakhovsky A. Protein kinase C $\delta$ controls self-antigen-induced B-cell tolerance. Nature. (2002) 416:860-5. doi: 10.1038/416860a

167. Miyamoto A, Nakayama K, Imaki H, Hirose S, Jiang Y, Abe M, et al. Increased proliferation of $\mathrm{B}$ cells and auto-immunity in mice lacking protein kinase $\mathrm{C} \delta$. Nature. (2002) 416:865-9. doi: 10.1038/416865a

168. Salzer E, Santos-Valente E, Keller B, Warnatz K, Boztug K. Protein kinase C $\delta$ : a gatekeeper of immune homeostasis. J Clin Immunol. (2016) 36:631-40. doi: 10.1007/s10875-016-0323-0

169. Booth C, Gilmour KC, Veys P, Gennery AR, Slatter MA, Chapel H, et al. $\mathrm{X}$-linked lymphoproliferative disease due to SAP/SH2D1A deficiency: a multicenter study on the manifestations, management and outcome of the disease. Blood. (2011) 117:53-62. doi: 10.1182/blood-2010-06-284935

170. Nagy N, Matskova L, Kis LL, Hellman U, Klein G, Klein E. The proapoptotic function of SAP provides a clue to the clinical picture of X-linked lymphoproliferative disease. Proc Natl Acad Sci USA. (2009) 106:11966-71. doi: $10.1073 /$ pnas. 0905691106

171. Nagy N, Matskova L, Hellman U, Klein G, Klein E. The apoptosis modulating role of SAP (SLAM associated protein) contributes to the symptomatology of the X linked lymphoproliferative disease. Cell Cycle. (2009) 8:3086-90. doi: 10.4161/cc.8.19.9636

172. Pachlopnik Schmid J, Canioni D, Moshous D, Touzot F, Mahlaoui N, Hauck F, et al. Clinical similarities and differences of patients with Xlinked lymphoproliferative syndrome type 1 (XLP-1/SAP deficiency) versus type 2 (XLP-2/XIAP deficiency). Blood. (2011) 117:1522-9. doi: 10.1182/blood-2010-07-298372

173. Ma CS, Hare NJ, Nichols KE, Dupré L, Andolfi G, Roncarolo M-G, et al. Impaired humoral immunity in X-linked lymphoproliferative disease is associated with defective IL-10 production by CD4+ T cells. J Clin Invest. (2005) 115:1049-59. doi: 10.1172/JCI200523139

174. Salvesen GS, Duckett CS. IAP proteins: blocking the road to death's door. Nat Rev Mol Cell Biol. (2002) 3:401-10. doi: 10.1038/nrm830

175. Ma CS, Nichols KE, Tangye SG. Regulation of cellular and humoral immune responses by the SLAM and SAP families of molecules. Annu Rev Immunol. (2007) 25:337-79. doi: 10.1146/annurev.immunol.25.022106.141651

176. Nichols KE, Ma CS, Cannons JL, Schwartzberg PL, Tangye SG. Molecular and cellular pathogenesis of X-linked lymphoproliferative disease. Immunol Rev. (2005) 203:180-99. doi: 10.1111/j.0105-2896.2005.00230.x

177. Oliveira JB, Bleesing JJ, Dianzani U, Fleisher TA, Jaffe ES, Lenardo MJ, et al. Revised diagnostic criteria and classification for the autoimmune lymphoproliferative syndrome (ALPS): report from the 2009 NIH International Workshop. Blood. (2010) 116:e35-40. doi: 10.1182/blood-2010-04-280347
178. Bride K, Teachey D. Autoimmune lymphoproliferative syndrome: more than a FAScinating disease. F1000Research. (2017) 6:1928. doi: 10.12688/f1000research.11545.1

179. Tarbox JA, Keppel MP, Topcagic N, Mackin C, Ben Abdallah M, Baszis KW, et al. Elevated double negative $\mathrm{T}$ cells in pediatric autoimmunity. J Clin Immunol. (2014) 34:594-9. doi: 10.1007/s10875-014-0038-z

180. Hillhouse EE, Lesage S. A comprehensive review of the phenotype and function of antigen-specific immunoregulatory double negative T cells. $J$ Autoimmun. (2013) 40:58-65. doi: 10.1016/j.jaut.2012.07.010

181. Alderson MR, Tough TW, Davis-Smith T, Braddy S, Falk B, Schooley KA, et al. Fas ligand mediates activation-induced cell death in human T lymphocytes. J Exp Med. (1995) 181:71-7. doi: 10.1084/jem.181.1.71

182. Dhein J, Walczak H, Bäumler C, Debatin K-M, Krammer PH. Autocrine T-cell suicide mediated by APO-1/(Fas/CD95). Nature. (1995) 373:438-41. doi: 10.1038/373438a0

183. Krueger A, Fas SC, Baumann S, Krammer PH. The role of CD95 in the regulation of peripheral T-cell apoptosis. Immunol Rev. (2003) 193:58-69. doi: $10.1034 / j .1600-065 X .2003 .00047 . x$

184. Le Deist F, Emile J-F, Rieux-Laucat F, Benkerrou M, Roberts I, Brousse $\mathrm{N}$, et al. Clinical, immunological, and pathological consequences of Fas-deficient conditions. Lancet. (1996) 348:719-23. doi: 10.1016/S0140-6736(96)02293-3

185. Lo B, Ramaswamy M, Davis J, Price S, Rao VK, Siegel RM, et al. A rapid ex vivo clinical diagnostic assay for fas receptorinduced T lymphocyte apoptosis. J Clin Immunol. (2013) 33:479-88. doi: $10.1007 / \mathrm{s} 10875-012-9811-z$

186. Nabhani S, Ginzel S, Miskin H, Revel-Vilk S, Harlev D, Fleckenstein B, et al. Deregulation of Fas ligand expression as a novel cause of autoimmune lymphoproliferative syndrome-like disease. Haematologica. (2015) 100:1189-98. doi: 10.3324/haematol.2014.114967

187. Kuehn HS, Caminha I, Niemela JE, Rao VK, Davis J, Fleisher TA, et al. FAS haploinsufficiency is a common disease mechanism in the human autoimmune lymphoproliferative syndrome. J Immunol. (2011) 186:603543. doi: 10.4049/jimmunol.1100021

188. Holland SM, DeLeo FR, Elloumi HZ, Hsu AP, Uzel G, Brodsky N, et al. STAT3 mutations in the Hyper-IgE syndrome. N Engl J Med. (2007) 357:1608-19. doi: 10.1056/NEJMoa073687

189. Milner JD, Vogel TP, Forbes L, Ma CA, Stray-Pedersen A, Niemela JE, et al. Early-onset lymphoproliferation and autoimmunity caused by germline STAT3 gain-of-function mutations. Blood. (2015) 125:591-9. doi: 10.1182/blood-2014-09-602763

190. Nabhani S, Schipp C, Miskin H, Levin C, Postovsky S, Dujovny T, et al. STAT3 gain-of-function mutations associated with autoimmune lymphoproliferative syndrome like disease deregulate lymphocyte apoptosis and can be targeted by BH3 mimetic compounds. Clin Immunol. (2017) 181:32-42. doi: 10.1016/j.clim.2017.05.021

191. Laurence A, Amarnath S, Mariotti J, Kim YC, Foley J, Eckhaus M, et al. STAT3 transcription factor promotes instability of nTreg cells and limits generation of iTreg cells during acute murine graft-versus-host disease. Immunity. (2012) 37:209-22. doi: 10.1016/j.immuni.2012.05.027

192. Huber M, Steinwald V, Guralnik A, Brustle A, Kleemann P, Rosenplanter C, et al. IL-27 inhibits the development of regulatory T cells via STAT3. Int Immunol. (2008) 20:223-34. doi: 10.1093/intimm/dxm139

193. Milner JD, Brenchley JM, Laurence A, Freeman AF, Hill BJ, Elias KM, et al. Impaired TH17 cell differentiation in subjects with autosomal dominant hyper-IgE syndrome. Nature. (2008) 452:773-6. doi: 10.1038/nature06764

194. Soler-Palacín P, Garcia-Prat M, Martín-Nalda A, Franco-Jarava C, Rivière JG, Plaja A, et al. LRBA deficiency in a patient with a novel homozygous mutation due to chromosome 4 segmental uniparental isodisomy. Front Immunol. (2018) 9:2397. doi: 10.3389/fimmu.2018. 02397

195. Lévy E, Stolzenberg M-C, Bruneau J, Breton S, Neven B, Sauvion $S$, et al. LRBA deficiency with autoimmunity and early onset chronic erosive polyarthritis. Clin Immunol. (2016) 168:88-93. doi: 10.1016/j.clim.2016.03.006

196. Gámez-Díaz L, August D, Stepensky P, Revel-Vilk S, Seidel MG, Noriko $\mathrm{M}$, et al. The extended phenotype of LPS-responsive beige-like anchor 
protein (LRBA) deficiency. J Allergy Clin Immunol. (2016) 137:223-30. doi: 10.1016/j.jaci.2015.09.025

197. Lo B, Zhang K, Lu W, Zheng L, Zhang Q, Kanellopoulou C, et al. Patients with LRBA deficiency show CTLA4 loss and immune dysregulation responsive to abatacept therapy. Science. (2015) 349:436-40. doi: $10.1126 /$ science.aaa1663

198. Charbonnier L-M, Janssen E, Chou J, Ohsumi TK, Keles S, Hsu JT, Massaad MJ, et al. Regulatory T-cell deficiency and immune dysregulation, polyendocrinopathy, enteropathy, X-linked-like disorder caused by loss-of-function mutations in LRBA. J Allergy Clin Immunol. (2015) 135:217-227.e9. doi: 10.1016/j.jaci.2014.10.019

199. Sebastian M, Lopez-Ocasio M, Metidji A, Rieder SA, Shevach EM, Thornton AM. Helios controls a limited subset of regulatory T cell functions. $J$ Immunol. (2016) 196:144-55. doi: 10.4049/jimmunol.1501704

200. Thornton AM, Korty PE, Tran DQ, Wohlfert EA, Murray PE, Belkaid Y, et al. Expression of Helios, an Ikaros transcription factor family member, differentiates thymic-derived from peripherally induced Foxp3 $+\mathrm{T}$ regulatory cells. J Immunol. (2010) 184:3433-41. doi: 10.4049/jimmunol.0904028

201. Jain N, Nguyen H, Chambers C, Kang J. Dual function of CTLA-4 in regulatory $\mathrm{T}$ cells and conventional $\mathrm{T}$ cells to prevent multiorgan autoimmunity. Proc Natl Acad Sci USA. (2010) 107:1524-8. doi: 10.1073/pnas.0910341107

202. Montgomery RA, Tatapudi VS, Leffell MS, Zachary AA. HLA in transplantation. Nat Rev Nephrol. (2018) 14:558-70. doi: 10.1038/s41581-018-0039-x

203. Serra P, Santamaria P. Antigen-specific therapeutic approaches for autoimmunity. Nat Biotechnol. (2019) 37:238-51. doi: 10.1038/s41587-019-0015-4

204. Anderson MS, Su MA. AIRE expands: new roles in immune tolerance and beyond. Nat Rev Immunol. (2016) 16:247-58. doi: 10.1038/nri.2016.9

205. Charbonnier L-M, Wang S, Georgiev P, Sefik E, Chatila TA. Control of peripheral tolerance by regulatory $\mathrm{T}$ cell-intrinsic Notch signaling. Nat Immunol. (2015) 16:1162-73. doi: 10.1038/ni.3288

206. Gambineri E, Ciullini Mannurita S, Hagin D, Vignoli M, Anover-Sombke S, DeBoer S, et al. Clinical, immunological, and molecular heterogeneity of 173 patients with the phenotype of immune dysregulation, polyendocrinopathy, enteropathy, x-linked (IPEX) syndrome. Front Immunol. (2018) 9:2411. doi: 10.3389/fimmu.2018.02411

207. Caudy AA, Reddy ST, Chatila T, Atkinson JP, Verbsky JW. CD25 deficiency causes an immune dysregulation, polyendocrinopathy, enteropathy, X-linked-like syndrome, and defective IL-10 expression from CD4 lymphocytes. J Allergy Clin Immunol. (2007) 119:482-7. doi: 10.1016/j.jaci.2006.10.007

208. Roifman CM. Human IL-2 receptor $\alpha$ chain deficiency. Pediatr Res. (2000) 48:6-11. doi: 10.1203/00006450-200007000-00004

209. Caldirola MS, Rodríguez Broggi MG, Gaillard MI, Bezrodnik L, Zwirner NW. Primary immunodeficiencies unravel the role of IL-2/CD25/STAT5b in human natural killer cell maturation. Front Immunol. (2018) 9:1429. doi: 10.3389/fimmu.2018.01429

210. Schubert D, Bode C, Kenefeck R, Hou TZ, Wing JB, Kennedy A, et al. Autosomal dominant immune dysregulation syndrome in humans with CTLA4 mutations. Nat Med. (2014) 20:1410-6. doi: 10.1038/nm.3746

211. Zheng Hou T, Verma N, Wanders J, Kennedy A, Soskic B, Janman D, et al. Identifying functional defects in patients with immune dysregulation due to LRBA and CTLA-4 mutations. Regul Artic Immunobiol. (2017) 129:1458-68. doi: 10.1182/blood-2016-10-745174

212. Friedline RH, Brown DS, Nguyen H, Kornfeld H, Lee J, Zhang Y, et al. CD4 ${ }^{+}$ regulatory $\mathrm{T}$ cells require CTLA- 4 for the maintenance of systemic tolerance. J Exp Med. (2009) 206:421-34. doi: 10.1084/jem.20081811

213. Mitsuiki N, Schwab C, Grimbacher B. What did we learn from CTLA-4 insufficiency on the human immune system? Immunol Rev. (2019) 287:3349. doi: 10.1111/imr.12721

214. Schwab C, Gabrysch A, Olbrich P, Patiño V, Warnatz K, Wolff D, et al. Phenotype, penetrance, and treatment of 133 cytotoxic T-lymphocyte antigen 4-insufficient subjects. J Allergy Clin Immunol. (2018) 142:1932-46. doi: $10.1016 /$ j.jaci.2018.02.055
215. Greene JL, Leytze GM, Emswiler J, Peach R, Bajorath J, Cosand W, et al. Covalent dimerization of CD28/CTLA-4 and oligomerization of CD80/CD86 regulate T cell costimulatory interactions. J Biol Chem. (1996) 271:26762-71. doi: 10.1074/jbc.271.43.26762

216. Egg D, Schwab C, Gabrysch A, Arkwright PD, Cheesman E, Giulino-Roth $\mathrm{L}$, et al. Increased risk for malignancies in 131 affected CTLA4 mutation carriers. Front Immunol. (2018) 9:2012. doi: 10.3389/fimmu.2018.02012

217. Zeissig S, Petersen B-S, Tomczak M, Melum E, Huc-Claustre E, Dougan SK, et al. Early-onset Crohn's disease and autoimmunity associated with a variant in CTLA-4. Gut. (2015) 64:1889-97. doi: 10.1136/gutjnl-2014-308541

218. Qureshi OS, Zheng Y, Nakamura K, Attridge K, Manzotti C, Schmidt $\mathrm{EM}$, et al. Trans-endocytosis of CD80 and CD86: a molecular basis for the cell-extrinsic function of CTLA-4. Science. (2011) 332:600-3. doi: 10.1126/science. 1202947

219. Muto A, Tashiro S, Nakajima O, Hoshino H, Takahashi S, Sakoda E, et al. The transcriptional programme of antibody class switching involves the repressor Bach2. Nature. (2004) 429:566-71. doi: 10.1038/nature02596

220. Roychoudhuri R, Hirahara K, Mousavi K, Clever D, Klebanoff CA, Bonelli M, et al. $\mathrm{BACH} 2$ represses effector programs to stabilize Treg-mediated immune homeostasis. Nature. (2013) 498:506-10. doi: 10.1038/nature12199

221. Heino M, Peterson P, Kudoh J, Shimizu N, Antonarakis SE, Scott HS, et al. APECED mutations in the autoimmune regulator (AIRE) gene. Hum Mutat. (2001) 18:205-11. doi: 10.1002/humu.1176

222. Ahonen P, Myllärniemi S, Sipilä I, Perheentupa J. Clinical variation of autoimmune polyendocrinopathy-candidiasis-ectodermal dystrophy (APECED) in a series of 68 patients. N Engl J Med. (1990) 322:1829-36. doi: 10.1056/NEJM199006283222601

223. Klein L, Kyewski B, Allen PM, Hogquist KA. Positive and negative selection of the T cell repertoire: what thymocytes see (and don't see). Nat Rev Immunol. (2014) 14:377-91. doi: 10.1038/nri3667

224. Nagafuchi S, Katsuta H, Koyanagi-Katsuta R, Yamasaki S, Inoue $Y$, Shimoda $\mathrm{K}$, et al. Autoimmune regulator (AIRE) gene is expressed in human activated $\mathrm{CD} 4+\mathrm{T}$-cells and regulated by mitogen-activated protein kinase pathway. Microbiol Immunol. (2006) 50:979-87. doi: 10.1111/j.1348-0421.2006.tb03876.x

225. Constantine GM, Lionakis MS. Lessons from primary immunodeficiencies: autoimmune regulator and autoimmune polyendocrinopathycandidiasis-ectodermal dystrophy. Immunol Rev. (2019) 287:103-20. doi: $10.1111 /$ imr.12714

226. Geier E, Pfeifer G, Wilm M, Lucchiari-Hartz M, Baumeister W, Eichmann $\mathrm{K}$, et al. A giant protease with potential to substitute for some functions of the proteasome. Science. (1999) 283:978-81. doi: 10.1126/science.283. 5404.978

227. Reits E, Neijssen J, Herberts C, Benckhuijsen W, Janssen L, Drijfhout $\mathrm{JW}$, et al. A major role for TPPII in trimming proteasomal degradation products for MHC class I antigen presentation. Immunity. (2004) 20:495506. doi: 10.1016/S1074-7613(04)00074-3

228. Rakhmanov M, Keller B, Gutenberger S, Foerster C, Hoenig M, Driessen G, et al. Circulating CD21low B cells in common variable immunodeficiency resemble tissue homing, innate-like B cells. Proc Natl Acad Sci USA. (2009) 106:13451-6. doi: 10.1073/pnas.0901984106

229. Moir S, Ho J, Malaspina A, Wang W, DiPoto AC, O'Shea MA, et al. Evidence for HIV-associated B cell exhaustion in a dysfunctional memory B cell compartment in HIV-infected viremic individuals. J Exp Med. (2008) 205:1797-805. doi: 10.1084/jem.20072683

230. Khodarev NN, Roizman B, Weichselbaum RR. Molecular pathways: interferon/stat1 pathway: role in the tumor resistance to genotoxic stress and aggressive growth. Clin Cancer Res. (2012) 18:3015-21. doi: 10.1158/1078-0432.CCR-11-3225

231. Levings MK, Sangregorio R, Roncarolo MG. Human $\operatorname{cd} 25(+) \operatorname{cd} 4(+) \mathrm{t}$ regulatory cells suppress naive and memory $\mathrm{T}$ cell proliferation and can be expanded in vitro without loss of function. J Exp Med. (2001) 193:1295-302. doi: 10.1084/jem.193.11.1295

232. Jonuleit H, Schmitt E, Stassen M, Tuettenberg A, Knop J, Enk AH. Identification and functional characterization of human CD4(+)CD25(+) $\mathrm{T}$ cells with regulatory properties isolated from peripheral blood. J Exp Med. (2001) 193:1285-94. doi: 10.1084/jem.193.11.1285 
233. Dieckmann D, Plottner H, Berchtold S, Berger T, Schuler G. Ex vivo isolation and characterization of $\mathrm{CD} 4(+) \mathrm{CD} 25(+) \mathrm{T}$ cells with regulatory properties from human blood. J Exp Med. (2001) 193:1303-10. doi: 10.1084/jem.193.11.1303

234. Rudensky AY. Regulatory T cells and Foxp3. Immunol Rev. (2011) 241:260-8. doi: 10.1111/j.1600-065X.2011.01018.x

235. Gobert M, Treilleux I, Bendriss-Vermare N, Bachelot T, Goddard-Leon $\mathrm{S}$, Arfi V, et al. Regulatory $\mathrm{T}$ cells recruited through CCL22/CCR4 are selectively activated in lymphoid infiltrates surrounding primary breast tumors and lead to an adverse clinical outcome. Cancer Res. (2009) 69:20009. doi: 10.1158/0008-5472.CAN-08-2360

236. Putnam AL, Brusko TM, Lee MR, Liu W, Szot GL, Ghosh T, et al. Expansion of human regulatory T-cells from patients with type 1 diabetes. Diabetes. (2009) 58:652-62. doi: 10.2337/db08-1168

237. Gavin MA, Torgerson TR, Houston E, DeRoos P, Ho WY, StrayPedersen A, et al. Single-cell analysis of normal and FOXP3-mutant human T cells: FOXP3 expression without regulatory T cell development. Proc Natl Acad Sci USA. (2006) 103:6659-64. doi: 10.1073/pnas.05094 84103

238. Wang J, Ioan-Facsinay A, van der Voort EIH, Huizinga TWJ, Toes REM. Transient expression of FOXP3 in human activated nonregulatory CD4+ T cells. Eur J Immunol. (2007) 37:129-38. doi: 10.1002/eji.2006 36435

239. Miyara M, Yoshioka Y, Kitoh A, Shima T, Wing K, Niwa A, et al. Functional delineation and differentiation dynamics of human CD4+ T cells expressing the FoxP3 transcription factor. Immunity. (2009) 30:899-911. doi: 10.1016/j.immuni.2009.03.019

240. Liu W, Putnam AL, Xu-Yu Z, Szot GL, Lee MR, Zhu S, et al. CD127 expression inversely correlates with FoxP3 and suppressive function of human CD4+ T reg cells. J Exp Med. (2006) 203:1701-11. doi: $10.1084 /$ jem.20060772

241. Seddiki N, Santner-Nanan B, Martinson J, Zaunders J, Sasson S, Landay A, et al. Expression of interleukin (IL)-2 and IL-7 receptors discriminates between human regulatory and activated T cells. J Exp Med. (2006) 203:1693700. doi: 10.1084/jem.20060468

242. Fuhrman CA, Yeh W-I, Seay HR, Saikumar Lakshmi P, Chopra G, Zhang L, et al. Divergent phenotypes of human regulatory $\mathrm{T}$ cells expressing the receptors TIGIT and CD226. J Immunol. (2015) 195:145-55. doi: 10.4049/jimmunol.1402381

243. Landuyt AE, Klocke BJ, Colvin TB, Schoeb TR, Maynard CL. Cutting edge: ICOS-deficient regulatory $\mathrm{T}$ cells display normal induction of IL-10 but readily downregulate expression of Foxp3. J Immunol. (2019) 202:1039-44. doi: 10.4049/jimmunol.1801266

244. Borsellino G, Kleinewietfeld M, Di Mitri D, Sternjak A, Diamantini A, Giometto R, et al. Expression of ectonucleotidase CD39 by Foxp3+ Treg cells: hydrolysis of extracellular ATP and immune suppression. Blood. (2007) 110:1225-32. doi: 10.1182/blood-2006-12064527

245. Gourdin N, Bossennec M, Rodriguez C, Vigano S, Machon C, Jandus C, et al. Autocrine adenosine regulates tumor polyfunctional CD73+CD4+ effector $\mathrm{T}$ cells devoid of immune checkpoints. Cancer Res. (2018) 78:3604-18. doi: 10.1158/0008-5472.CAN-17-2405

246. Álvarez-Sánchez N, Cruz-Chamorro I, Díaz-Sánchez M, Lardone PJ, Guerrero JM, Carrillo-Vico A. Peripheral CD39-expressing T regulatory cells are increased and associated with relapsing-remitting multiple sclerosis in relapsing patients. Sci Rep. (2019) 9:2302. doi: 10.1038/s41598-019-38897-w

247. Hippen KL, Merkel SC, Schirm DK, Sieben CM, Sumstad D, Kadidlo DM, et al. Massive ex vivo expansion of human natural regulatory T cells (T(regs)) with minimal loss of in vivo functional activity. Sci Transl Med. (2011) 3:83ra41. doi: 10.1126/scitranslmed.3001809

248. Jin X, Lu Y, Zhao Y, Yi S. Large-scale in vitro expansion of human regulatory $\mathrm{T}$ cells with potent xenoantigen-specific suppression. Cytotechnology. (2016) 68:935-45. doi: 10.1007/s10616-015-9845-1

249. Battaglia M, Stabilini A, Migliavacca B, Horejs-Hoeck J, Kaupper T, Roncarolo M-G. Rapamycin promotes expansion of functional $\mathrm{CD}^{+} \mathrm{CD} 25+$ FOXP3 + regulatory $\mathrm{T}$ cells of both healthy subjects and type 1 diabetic patients. J Immunol. (2006) 177:8338-47. doi: 10.4049/jimmunol.177.12.8338

250. McMurchy AN, Levings MK. Suppression assays with human $T$ regulatory cells: a technical guide. Eur J Immunol. (2012) 42:27-34. doi: 10.1002/eji.201141651

251. Engelhardt KR, Shah N, Faizura-Yeop I, Kocacik Uygun DF, Frede N, Muise AM, et al. Clinical outcome in IL-10- and IL-10 receptor-deficient patients with or without hematopoietic stem cell transplantation. J Allergy Clin Immunol. (2013) 131:825-30.e9. doi: 10.1016/j.jaci.2012.09.025

252. Begue B, Verdier J, Rieux-Laucat F, Goulet O, Morali A, Canioni D, et al. Defective IL10 signaling defining a subgroup of patients with inflammatory bowel disease. Am J Gastroenterol. (2011) 106:1544-55. doi: 10.1038/ajg.2011.112

253. O’Donnell EA, Ernst DN, Hingorani R. Multiparameter flow cytometry: advances in high resolution analysis. Immune Netw. (2013) 13:43-54. doi: 10.4110/in.2013.13.2.43

254. Villani A-C, Sarkizova S, Hacohen N. Systems immunology: learning the rules of the immune system. Annu Rev Immunol. (2018) 36:813-42. doi: 10.1146/annurev-immunol-042617-053035

255. Davis MM, Tato CM, Furman D. Systems immunology: just getting started. Nat Immunol. (2017) 18:725-32. doi: 10.1038/ni.3768

256. Choi J, Fernandez R, Maecker HT, Butte MJ. Systems biology approach to uncover signaling defects in primary immunodeficiency diseases. J Immunol. (2016) 196(1 Suppl.):209.7.

257. Choi J, Fernandez R, Maecker HT, Butte MJ. Systems approach to uncover signaling networks in primary immunodeficiency diseases. J Allergy Clin Immunol. (2017) 140:881-4.e8. doi: 10.1016/j.jaci.2017.03.025

Conflict of Interest: EO was employed by company Immunogenic Inc., Brazil.

The remaining authors declare that the research was conducted in the absence of any commercial or financial relationships that could be construed as a potential conflict of interest.

Copyright (C) 2019 Cabral-Marques, Schimke, de Oliveira, El Khawanky, Ramos, Al-Ramadi, Segundo, Ochs and Condino-Neto. This is an open-access article distributed under the terms of the Creative Commons Attribution License (CC BY). The use, distribution or reproduction in other forums is permitted, provided the original author(s) and the copyright owner(s) are credited and that the original publication in this journal is cited, in accordance with accepted academic practice. No use, distribution or reproduction is permitted which does not comply with these terms. 